\title{
Review \\ Fanconi Anemia Pathway in Colorectal Cancer: A Novel Opportunity for Diagnosis, Prognosis and Therapy
}

\author{
Fatemeh Ghorbani Parsa ${ }^{1}$, Stefania Nobili ${ }^{2,3}{ }^{(D}$, Mina Karimpour ${ }^{4}$ (D), Hamid Asadzadeh Aghdaei ${ }^{1}$, \\ Ehsan Nazemalhosseini-Mojarad ${ }^{5, *}$ and Enrico Mini ${ }^{6,7, *(D)}$
}

1 Basic and Molecular Epidemiology of Gastrointestinal Disorders Research Center, Research Institute for Gastroenterology and Liver Diseases, Shahid Beheshti University of Medical Sciences, Tehran 19857-17413, Iran; ghorbaniparsa@tabrizu.ac.ir (F.G.P.); hamid.asadzadeh@sbmu.ac.ir (H.A.A.)

2 Department of Neurosciences, Imaging and Clinical Sciences, University “G. D'Annunzio" Chieti-Pescara, 66100 Chieti, Italy; stefania.nobili@unich.it

3 Center for Advanced Studies and Technology (CAST), University “G. D'Annunzio" Chieti-Pescara, 66100 Chieti, Italy

4 Department of Genetics, Faculty of Biological Sciences, Tarbiat Modares University, Tehran 14115-154, Iran; mina.karimpour@modares.ac.ir

5 Gastroenterology and Liver Diseases Research Center, Research Institute for Gastroenterology and Liver Diseases, Shahid Beheshti University of Medical Sciences, Tehran 19857-17413, Iran

6 Department of Health Sciences, University of Florence, 50139 Florence, Italy

7 DENOTHE Excellence Center, University of Florence, 50139 Florence, Italy

* Correspondence: e.nazemalhosseini@sbmu.ac.ir (E.N.-M.); enrico.mini@unifi.it (E.M.)

check for

updates

Citation: Parsa, F.G.; Nobili, S.;

Karimpour, M.; Aghdaei, H.A.;

Nazemalhosseini-Mojarad, E.; Mini,

E. Fanconi Anemia Pathway in

Colorectal Cancer: A Novel

Opportunity for Diagnosis, Prognosis and Therapy. J. Pers. Med. 2022, 12,

396. https://doi.org/10.3390/ jpm12030396

Academic Editor: Liang Cheng

Received: 7 February 2022

Accepted: 2 March 2022

Published: 4 March 2022

Publisher's Note: MDPI stays neutral with regard to jurisdictional claims in published maps and institutional affiliations.

Copyright: (C) 2022 by the authors. Licensee MDPI, Basel, Switzerland. This article is an open access article distributed under the terms and conditions of the Creative Commons Attribution (CC BY) license (https:// creativecommons.org/licenses/by/ $4.0 /)$.

\begin{abstract}
Colorectal cancer (CRC) is the third most commonly diagnosed malignancy and has the second highest mortality rate globally. Thanks to the advent of next-generation sequencing technologies, several novel candidate genes have been proposed for CRC susceptibility. Germline biallelic mutations in one or more of the 22 currently recognized Fanconi anemia (FA) genes have been associated with Fanconi anemia disease, while germline monoallelic mutations, somatic mutations, or the promoter hypermethylation of some FANC genes increases the risk of cancer development, including CRC. The FA pathway is a substantial part of the DNA damage response system that participates in the repair of DNA inter-strand crosslinks through homologous recombination (HR) and protects genome stability via replication fork stabilization, respectively. Recent studies revealed associations between FA gene/protein tumor expression levels (i.e., FANC genes) and CRC progression and drug resistance. Moreover, the FA pathway represents a potential target in the CRC treatment. In fact, FANC gene characteristics may contribute to chemosensitize tumor cells to DNA crosslinking agents such as oxaliplatin and cisplatin besides exploiting the synthetic lethal approach for selective targeting of tumor cells. Hence, this review summarizes the current knowledge on the function of the FA pathway in DNA repair and genomic integrity with a focus on the FANC genes as potential predisposition factors to CRC. We then introduce recent literature that highlights the importance of FANC genes in CRC as promising prognostic and predictive biomarkers for disease management and treatment. Finally, we represent a brief overview of the current knowledge around the FANC genes as synthetic lethal therapeutic targets for precision cancer medicine.
\end{abstract}

Keywords: colorectal cancer; Fanconi anemia; prognostic biomarker; predictive biomarker; target therapy; synthetic lethality

\section{Introduction}

Colorectal cancer (CRC) is the second most lethal cancer globally [1]. Approximately $20 \%$ to $30 \%$ of CRCs are potentially linked to genetic factors, although the most underlying genetic causes remain unexplained [2]. However, the Mendelian CRC syndromes with defined genetic predispositions account for approximately $5 \%$ to $10 \%$ of all CRC syndromes [3]. These well-defined hereditary CRCs are caused by pathogenic mutations or 
epimutations in DNA mismatch repair (MMR) genes- $M L H 1, M S H 2, M S H 6$, and PMS2 for nonpolyposis CRC cases and pathogenic variants (PVs) in MUTYH and NTHL (recessive inheritance) along with those in APC for adenomatous polyposis syndromes $[2,4]$.

Other-less frequent-CRC-predisposing syndromes, characterized by the presence of hamartomatous polyps, are caused by mutations in SMAD4, BMPR1A, STK11, and PTEN [5]. Additionally, some syndromes are still being further characterized, such as the I1307K polymorphism in APC as well as the polymerase proofreading-associated polyposis (PPAP) caused by the germline mutations in POLE and POLD1 [6-9]. There are also some other CRC syndromes, such as serrated polyposis syndrome, the causative genes of which are not fully understood [10]. However, besides these well-defined predisposing genes, several non-CRC hereditary cancer genes have been recently found to be mutated in CRC patients, which might be connected with an increased risk of CRC or adenomatous polyposis [5,11].

Interestingly, the knowledge of the microsatellite status (i.e., MSS or MSI), strictly related to an impaired MMR system, is today widely informative not only in terms of CRC predisposition (i.e., Lynch syndrome diagnosis) but also in terms of prognosis and therapeutic options. In fact, MSI identifies a subset of CRC patients (i.e., low-risk stage II patients) at better prognosis who do not achieve advantages from adjuvant chemotherapy. In addition, the MSI-H condition is a prominent biomarker for the treatment of several tumors, including metastatic CRC, with immune checkpoint inhibitors. Thus, the evaluation of MMR/MSI has become part of the standard diagnostic and therapeutic course in CRC. Therefore, the major oncological international societies recommend the use of immune checkpoint inhibitors in the treatment of metastatic CRC either as first-line treatment or as subsequent therapy after the front-line treatment $[3,12,13]$.

Fanconi anemia (FA) is a rare autosomal recessive genetic disease characterized by bone marrow failure, cancer susceptibility, and developmental abnormalities that originate from biallelic mutations in at least one of 22 FANC genes (designated as FA complementation groups), which have been identified so far [14]. The 22 FANC genes are FANCA, FANCB, FANCC, FANCD1/BRCA2, FANCD2, FANCE, FANCF, FANCG, FANCI, FANCJ/BRIP1, FANCL, FANCM, FANCN/PALB2, FANCO/RAD51C, FANCP/SLX4, FANCQ/ERCC4, FANCR/Rad51, FANCS/BRCA1, FANCT/UBE2T, FANCU/XRCC2, FANCV/REV7 and FANCW/RFWD3 [15]. All the FA genes show autosomal recessive inheritance except for the X-linked FANCB gene and FANCR/RAD51 gene, whose dominant mutations are associated with FA-like syndrome $[16,17]$.

The products of these 22 FANC genes cooperate in a cellular repair pathway known as the FA pathway or the FA-BRCA pathway, emphasizing that some of the FA proteins are BRCA-related proteins [18]. This pathway plays a pivotal role in the repair of DNA inter-strand crosslink by the combined actions of nucleotide excision repair (NER), homologous recombination (HR), and trivial involvement of the translesion DNA synthesis (TLS) pathway $[19,20]$. DNA inter-strand crosslinks are covalent linkages between two complementary strands of DNA that block DNA strand separation upon replication and transcription. Unresolved DNA inter-strand crosslink creates clastogenic effects leading to genomic instability, a critical event in the accumulation of genetic mutations, which trigger cancer initiation [21,22].

The connection between the FA pathway and malignancy was evidenced when mutations in FANCD1/BRCA2, the breast/ovarian cancer susceptibility gene, had been detected in FA patients $[20,23]$. It is known that the biallelic mutations in FANC genes lead to Fanconi anemia disease, while germline monoallelic mutations, somatic mutations, or promoter hypermethylation of some FANC genes increase the risk of cancer in non-FA individuals [24,25]. For instance, it is well established that monoallelic mutations in FANCS/BRCA1 and/or FANCD1/BRCA2 are associated with breast and ovarian cancer susceptibility [17]. Genomic alterations that involve other genes in HR pathways, including FANCJ/BRIP1 and FANCN/PALB2, have also been suggested to increase the lifetime risk of epithelial ovarian cancer development [26]. Recently, the identification of mutations in FANC genes such as 
FANCD1/BRCA2 [27,28], FANCJ/BRIP1 [27,29], FANCN/PALB2 [27,30], and FANCA [29,31], among CRC patients who did not harbor detectable mutations in known CRC susceptibility genes, highlights the role of $F A N C$ genes as potential CRC predisposition genes.

Thus, this narrative review aims to provide an overview of the function of FANC genes in CRC predisposition, progression, and drug resistance, in addition to their potential clinical value as predictive and/or prognostic biomarkers, after representing a summary of the FA pathway role in the repair of DNA lesions and the protection of genomic stability. However, investigation into the function of FANC genes in CRC occurrence is still in its infancy. To our knowledge, this review is the first attempt to summarize current knowledge on the implication of FANC genes in CRC. Although there is little evidence regarding this subject currently, we assume that more information will emerge in the next future.

\section{The Fanconi Anemia Pathway in DNA Repair and Maintenance of Genome Integrity}

The FA pathway is a biochemical network that actively participates in the DNA repair and genome integrity maintenance processes through resolving DNA inter-strand crosslinking damages, participating in replication fork stability, and cytokinesis [32]. Of these, its canonical function is the inter-strand crosslink repair [33].

\subsection{The FA Pathway and Inter-Strand Crosslink Repair}

DNA crosslinking damages are caused by the covalent linkage between two nucleotides residing on either two complementary strands of DNA (inter-strand crosslink) or the same DNA strand (intra-strand crosslink) [34]. These crosslinks might arise from either exogenous sources such as mitomycin $C$ and platinum-based chemotherapeutic agents or derive from endogenous metabolites comprising aldehydes and nitrous acid, to name a few $[14,33]$. Although intra-strand crosslinks are easily eliminated by the nucleotide excision repair (NER) pathway, inter-strand crosslinks must be repaired through the FA pathway involving several steps and proteins [14]. As shown in Figure 1, the proteins encoded by FANC genes in conjunction with several FA-associated factors collaborate to overcome inter-strand crosslink lesions [14]. The FA pathway triggers inter-strand crosslink repair principally during the $S$ phase of the cell cycle by detecting two converging replication forks that formed the $\mathrm{X}$ shape construct near the inter-strand crosslink site [35]. In this procedure, FANCM, along with some other FA-associated proteins (FAAPs), senses the stalled replication fork on inter-strand crosslink damage. They act as the loading platform for assembling proteins of the FA core complex, including FANCA, B, C, E, F, G, L, M, T, and histone fold dimer proteins (MHF1, MHF2) (Figure 1a) $[32,36]$. The FA core complex as a ubiquitin-ligase conducts the formation and activation of FANCI-FANCD2 heterodimer (ID2 complex) through monoubiquitylation (Figure 1b) [37]. Monoubiquitylated ID2 in a process known as 'unhooking' governs nucleolytic incision at collapsed replication forks to cleave the inter-strand crosslink $[14,36]$. In this process, ubiquitylated FANCD2 recruits and activates several endonucleases comprising FANCP/SLX4, ERCC1-ERCC4 (ERCC4, also named FANCQ) heterodimers, and FAN1 (Fanconi-associated nuclease 1) to tackle the inter-strand crosslink lesion (Figure 1c) [32]. These endonucleases incise the ICL and leave it on one duplex while generating a double-strand break (DSB) on the other duplex [38]. Although the inter-strand crosslink is bypassed by translesion synthesis, the DSBs are repaired by HR (Figure 1d) [39]. For HR, a DSB is detected first by poly (ADP-ribose) polymerase 1 (PARP1) during the $\mathrm{S}$ phase. Then, PARP1 marks the lesion site by attaching ADP-ribose molecules to chromatin-bound proteins neighboring the break (Figure 1e) [40]. Consequently, ADPribose units recruit the MRE11-RAD50-NBS (MRN) complex to produce single-strand DNA (ssDNA) around the break (Figure 1f) [41]. Meanwhile, some FA components, including FANCS/BRCA1, FANCD1/BRCA2, BRIP1/FANCJ, and PALB2/FANCN, along with the RAD51B-FANCO/RAD51C-RAD51D-FANCU/XRCC2 (BCDX2) complex, promote the attachment of FANCR/RAD51 to the ssDNA overhangs. Finally, FANCR completes 
the HR repair via attacking the homologous DNA region (Figure 1g) [42]. Indeed, the FA pathway grants the high-fidelity repair of the ICL damages through blocking the error-prone NHEJ pathway and recruiting the FA-pathway-dependent HR repair [32,33].

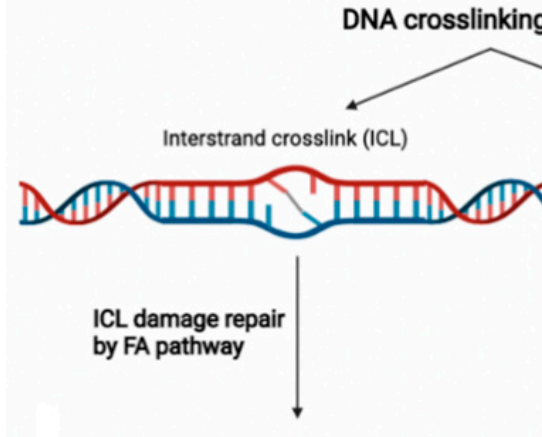

(a) ICL recognition at converging replication fork

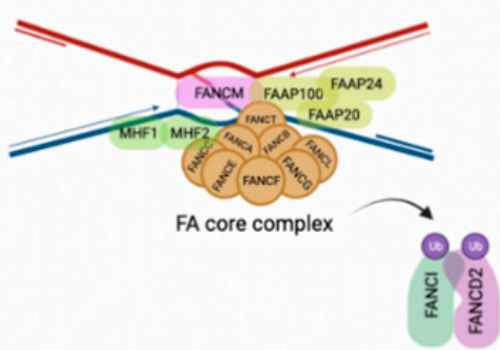

(g) Strand invasion and DNA synthesis

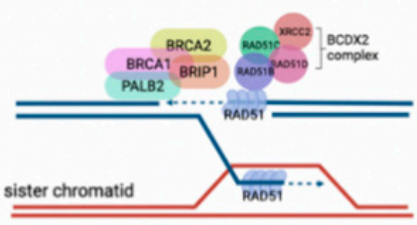

(c) Unhooking processing

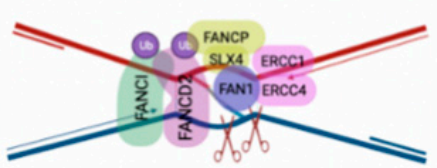

(b) ID2 monoubiquitination

(f) MRN complex loading to produce ssDNA

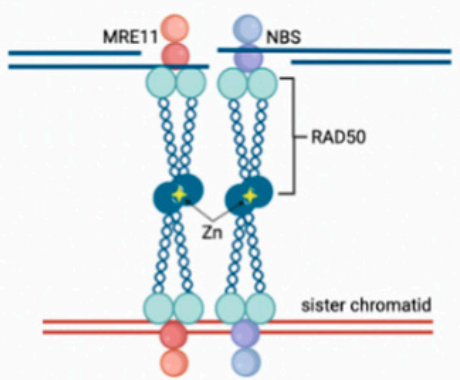

by NER pathway
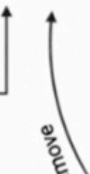

(d) ICL bypass by TLS

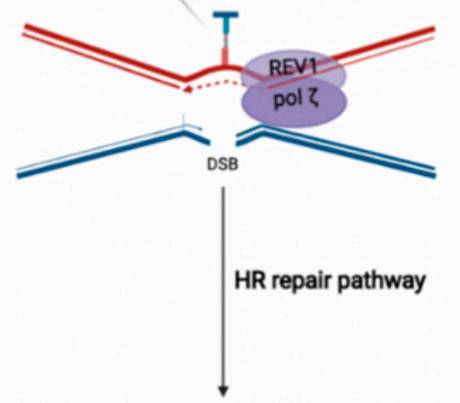

(e) Detection of DSB

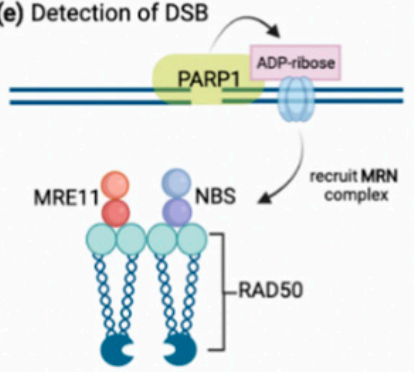

Figure 1. The FA pathway and inter-strand crosslink (ICL) repair. DNA crosslinking damages generally include intra-strand and inter-strand crosslink damages, which are repaired by NER and FA pathways, respectively. (a) In the FA pathway, the ICL damage is recognized by FANCM accompanying some other FAAPs at converging replication fork, which results in FA core complex loading along with FAAP100, FAAP20, and FAAP24, as well as MHF1 and MHF2. (b) FA core complex activates the ID2 complex by monoubiquitylation of FANCI and FANCD2. (c) Monoubiquitylated ID2 complex activates several endonucleases, such as FAN1, to stimulate unhooking processing of the ICL. (d) The unhooked ICL is removed by the NER pathway and bypassed by translesion synthesis polymerases REV1/pol $\zeta$. (e,f) The HR pathway is recruited to repair the DSB on the other strand. After detection of DSB by PARP1, ADP-ribose molecules recruit the MRN complex to produce single-strand DNA and bind sister chromatid through a tail-to-tail link with another MRN complex. (g) Some FA members, such as BRCA1, BRCA2, BRIP1, and PALB2, in addition to the BCDX2 complex, induce the attachment of FANCR/RAD51 to ssDNA, which promotes strand invasion and DNA synthesis.

Due to the importance of the HR pathway in cancer progression and drug resistance [43], the cancer relevance of FANC gene alterations at DNA and gene expression levels in various cancers has been considered. For example, germline mutations in FANCD2, the representative of the FA pathway, are likely linked with the increased risk of metastatic CRC [44]. The overexpression of FANCD2 also predicts the increased proba- 
bility of either lymph node metastasis or liver metastasis, which is reasonably associated with poor prognostic outcomes among CRC patients [45]. Since the monoubiquitylation of FANCD2 is a vital step in the FA pathway, its inhibition might selectively kill tumor cells [46]. All these observations highlight the conserved role of FANC genes in inter-strand crosslink repair.

\subsection{FA Proteins Stabilize Stalled Replication Forks}

One critical cellular process that contributes to DNA disruption is DNA replication. Upon DNA duplication, cells might encounter the challenges, such as stalled replication fork [47]. Replication fork slowing or stalling defines the replication stress, which causes chromosomal instability and tumor progression [48-50]. Recent data suggest that independent of inter-strand crosslink and HR repair, the FA proteins are essential to preserving genome stability upon replication stress [15]. Replication stress arises from endogenous or exogenous sources that interfere with the movement of the replication machinery and faithful duplication [48].

The principal endogenous source of fork stalling and DNA break is R-loop [21]. Rloops are three-stranded RNA:DNA structures mainly created from transcription-replication complex collision [51]. FA proteins actively protect cells from either R-loop formation or accumulation $[52,53]$. Using novel sequencing methods (DNA:RNA immunoprecipitation with deep sequencing), it was detected that FANCD2 or FANCA deficiency causes a higher level of R-loop formation in murine or human cell lines [52]. Intriguingly, some investigations showed that FANCD2 overexpression limits replication stress and genome instability in BRCA1/2-deficient tumors [54]. Furthermore, FANCM helicase resolves R-loops obstacles via its translocase activity. It facilitates the displacement of RNA from R-loop structures in the absence of RNaseH (typical RNase to remove RNA-DNA hybrid) [55].

The G-quadruplex secondary structure (G4), guanine-rich regions of DNA that fold into four-stranded DNA structures, is another endogenous source of fork stalling that interferes with the progression of DNA replication [56]. The increased level of G-quadruplex structures has been diagnosed in various cancers that underlie genomic instability $[57,58]$. FANCJ helicase resolves the G4 DNA structure to support DNA replication and maintenance of genome integrity [59]. In such a scenario, FANCJ recognizes and unfolds the G4 structure through a specific motif, its helicase activity, in addition to recruiting REV1 polymerase $[59,60]$. Intriguingly, growing evidence has proposed that small molecules selectively bind and stabilize G4 DNA structures, which results in the inhibition of FANCJ unwinding activity on a variety of G4 DNA structures [61,62]. Therefore, DNA helicases might be potential targets in cancer therapy by exploiting the synthetic lethality approaches $[63,64]$. In this respect, Wu et al. [65] have shown that FANCJ deficiency leads to enhanced sensitivity to a G4-stabilizing ligand known as telomestatin (TMS). Similarly, a recent study reproduced these findings by using a G4-specific antibody. These findings demonstrated that exposure to TMS in FANCJ-deficient cells results in increased G4 formation and genomic instability [66].

Moreover, another source of fork stalling is dNTP pool depletion, which might be induced by chemotherapeutic agents such as hydroxyurea, an inhibitor of ribonucleotide reductase [67]. At high doses of hydroxyurea, FANC genes act to resolve the increased number of stalled replication forks. In such a situation, FANCD2 prevents MRE11-nascent DNA degradation. Moreover, FANCR/RAD51 and FANCD1/S (BRCA1/2) proteins promote the replication restart [68]. For instance, a cell lineage study showed the increased sensitivity to hydroxyurea in FANCR and FANCD2 knockdown and deficient cells [69].

All of the above studies verified that FA proteins are principally involved in DNA repair. Accordingly, unrepaired DNA lesions lead to genome instability, which fuels the initiation of malignancies. Considering the growing evidence suggesting the role of FANC genes in increased susceptibility to CRC, we provide an overview of FANC genes that have been proposed to predispose to CRC. 


\section{Potential Role of FANC Gene Mutations in Colorectal Cancer Susceptibility}

Deficiency in MMR proteins has been generally used for CRC classification, while mutations in HR and FANC genes have been connected to hereditary breast-ovarian cancer syndrome [41] or have been reported in a higher percentage in metastatic castrationresistance prostate cancer compared with the localized disease [70]. Despite this fact, recent studies suggest that germline heterozygous mutations in some FANC genes increase the risk of developing CRC in non-FA patients [27,28,30,71-74]. Indeed loss-of-function mutations in HR genes result in the aggregation of DSB damages, hampering genomic stability and leading to cancer development. Although the proof of causation is not fully understood [5,41], it is well-established that MMR proteins, which play a crucial role in CRC, contribute to DNA double-strand HR repair [75,76]. In addition, previous findings have confirmed a direct interaction between MMR proteins and some FA proteins, such as FANCJ/MLH1 [77], FANCS/MSH2/MSH6/MLH2 [78], and FANCD2/MSH2/MLH1 [79] (see more details in Figure 2). Therefore, from this perspective, it is reasonable to speculate that PVs in FANC genes may be associated with the increased risk of CRC. Significantly, genetic testing of patients diagnosed with CRC not only can drive treatment but also facilitate earlier cancer screening for patients and their at-risk relatives. However, the optimal panel of genes for assessing the risk of CRC is not established yet.

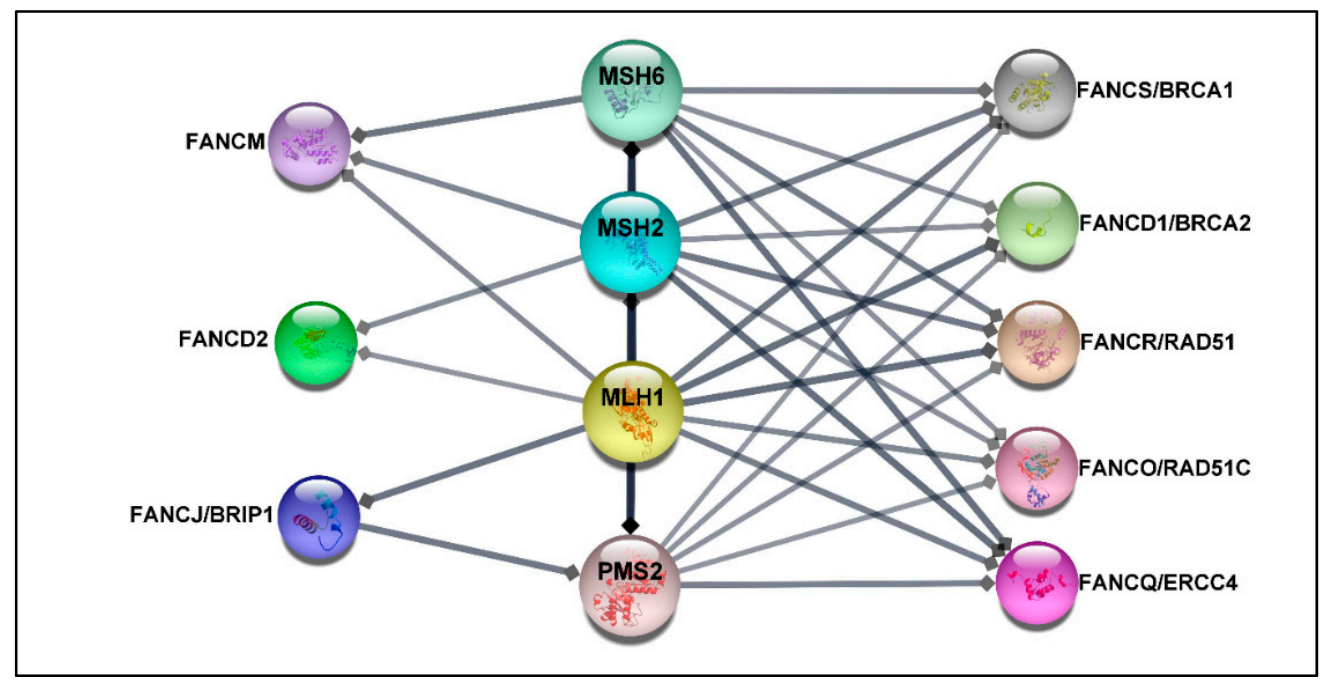

Figure 2. The protein-protein network. The protein-protein interaction (PPI) between MMR proteins comprising MLH1, MSH2, MSH6, PMS2, and 22 FA proteins was exported from the STRING database (high confidence (0.7)) [80] and visualized by using Cytoscape software, version 3.8.2 [81]. The association network shows that FANCS, FANCD1, FANCO, and FANCQ are linked with all selected MMR proteins, while FANCM interacts with MSH6, MSH2, and MLH1. FANCD2 is connected to MSH2 and MLH1, whereas FANCJ is associated with MLH1 and PMS2. The FA proteins without direct association with selected MMR proteins have been excluded.

\subsection{Germline Monoallelic Mutations}

As summarized in Table 1, among 22 FANC genes, FANCS/BRCA1 and FANCD2/BRCA2, high-risk hereditary breast-ovarian cancer syndrome susceptibility genes, are the most investigated as CRC susceptibility genes beyond its well-known predispositions [27-31,44,73,82-89]. Recent findings revealed that the prevalence of $B R C A 1 / 2$ PVs among early-onset (1.3\%) [30] and unselected patients with CRC (3.9\%) [88] is more frequent than would be happening by chance. Likewise, the connection between the FANCD1 mutation and increased risk of CRC has also been demonstrated among probands with familial CRC type X $(2 / 48)$ [85]. For instance, in 2017, a prospective study of multigene panel testing by Pearlman et al. [30] examined the frequency of $B R C A 1 / 2$ mutations in 450 CRC patients younger than 50 years (early-onset CRC). The results indicated that six patients harbored mutations in BRCA1/2 
without changes in known CRC predispositions. Unexpectedly, two of them did not have a personal or familial history of breast or ovarian cancer. Likewise, Yurgelon et al. [27] assessed the prevalence of BRCA1/2 mutations among 1058 unselected CRC patients. They also identified pathogenic mutations in BRCA2 and BRCA1 as the cause of CRC in eight and three individuals, respectively [27]. In addition, a large cohort study including 2398 unselected CRC patients demonstrated that the median age of CRC diagnosis in $B R C A 1$ mutation carriers was seven years lower than that of non-carriers, suggesting that BRCA1 mutations might be linked with early-onset CRC [90]. Likewise, the notion of the association between $B R C A 1$ mutation and early-onset CRC has been verified in another international study involving a cohort of 7105 female patients harboring $B R C A 1 / 2$ PVs [91]. However, in contrast with these findings, a valuable investigation on a total of 6396 CRC tumor specimens did not find any significant association between BRCA1/2 mutation and age [88]. Similarly, Cullinane et al. [92] presented a systematic review and meta-analysis including eleven studies for a total of 4831 CRC patients to assess the CRC risk in BRCA mutation carriers. Their fruitful study did not show any statistically significant increase in CRC development among BRCA1/2 mutation carriers, regardless of the age or ethnicity of patients. Overall, despite all genuine attempts, the significance of BRCA mutation in CRC incidence remains controversial and, still, there are no specific guidelines or recommendations for gastric and bowel screening procedures for carriers of $B R C A 1 / 2$ mutations [93].

Besides BRCA1/2, the implication in CRC occurrence of FANCJ/BRIP1 mutations, a moderate-risk factor for ovarian cancer, has attracted considerable attention [27-29,83,86,94,95]. As summarized in Table 1, recent studies detected that pathogenic germline FANCJ/BRIP1 mutations are likely associated with the increased risk of developing CRC. For instance, Yurgelun et al. [27] and Gong et al. [29] have identified FANCJ PVs in 3 out of 1058 and 2 out of 618 unselected CRC patients, respectively. Likewise, the correlation between FANCJ mutation and increased risk of CRC has also been ascertained among familial CRC patients without germline PVs in known CRC predispositions (1/74) [28]. However, these reports are not sufficient to conclude on the role of FANCJ mutations in CRC, and further investigations are needed to ascertain if this association is significant.

Table 1. Germline mutations in FANC genes among CRC patients without mutations in known CRC predisposition genes.

\begin{tabular}{|c|c|c|c|c|}
\hline Gene(s) and No. & Study Group & Study Method & $\begin{array}{l}\text { N. of FANC Gene } \\
\text { Mutation Carriers } \\
\text { in CRC Patients }\end{array}$ & Reference \\
\hline FANCD1/BRCA2: 2 & $\begin{array}{l}2 \text { patients from } 1 \text { family, no } \\
\text { mutations in known CRC genes }\end{array}$ & $\begin{array}{l}\text { Point mutation screening of } \\
\text { the } B R C A 1 \text { and } B R C A 2 \text { genes }\end{array}$ & $2 / 2$ & [73] \\
\hline FANCD1/BRCA2: 2 & $\begin{array}{l}48 \text { FCCTX probands with strong } \\
\text { familial CRC aggregation; no } \\
\text { mutations in known CRC genes }\end{array}$ & Mutation screening of $B R C A 2$ & $2 / 48$ & {$[85]$} \\
\hline $\begin{array}{l}\text { FANCD1/BRCA2: } 9 \\
\text { FANCS/BRCA1: } 6 \\
\text { FANCJ/BRIP1: } 2\end{array}$ & $\begin{array}{l}1260 \text { CRC patients with } \\
\text { suspected Lynch syndrome }\end{array}$ & 25-gene NGS panel testing & $17 / 1260$ & {$[86]$} \\
\hline $\begin{array}{l}\text { FANCS/BRCA1: } 4 \\
\text { FANCD1/BRCA2: } 1 \\
\text { FANCN/PALB2: } 2\end{array}$ & 450 EOCRC patients & 25-gene NGS panel testing & $7 / 450$ & [30] \\
\hline FANCS/BRCA1: 1 & 430 EOCRC patients $<50$ years & 154-gene NGS panel testing & $1 / 430$ & [87] \\
\hline
\end{tabular}


Table 1. Cont.

\begin{tabular}{|c|c|c|c|c|}
\hline Gene(s) and No. & Study Group & Study Method & $\begin{array}{l}\text { N. of FANC Gene } \\
\text { Mutation Carriers } \\
\text { in CRC Patients }\end{array}$ & Reference \\
\hline $\begin{array}{l}\text { FANCI:1, FANCL: } 1 \\
\text { FANCO/RAD51C: } 1 \\
\text { FANCQ/ERCC4: } 1 \\
\text { FANCS/BRCA1: } 1 \\
\text { FANCU/XRCC2: } 1\end{array}$ & $\begin{array}{l}330 \text { mCRC patients age } \leq 55 \\
\text { years, } \\
110 \text { mCRC patients age }>55 \\
\text { years }\end{array}$ & 98-gene NGS panel testing & $6 / 440$ & [44] \\
\hline $\begin{array}{l}\text { FANCD1/BRCA2: } 179 \\
\text { FANCS/BRCA1: } 72\end{array}$ & 6396 unselected CRC samples & 592-gene NGS panel testing & $251 / 6396$ & [88] \\
\hline $\begin{array}{l}\text { FANCD1/BRCA2: } 8 \\
\text { FANCJ/BRIP1: } 3 \\
\text { FANCS/BRCA1: } 3 \\
\text { FANCN/PALB2: } 2\end{array}$ & 1058 unselected CRC samples & 25-gene NGS panel testing & $16 / 1058$ & [27] \\
\hline FANCN/PALB2: 3 & 680 unselected CRC patients & 40-gene NGS panel testing & $3 / 680$ & [72] \\
\hline $\begin{array}{l}\text { FANCD1/BRCA2: } 1 \\
\text { FANCS/BRCA1: } 1\end{array}$ & 618 unselected CRC patients & 73-gene NGS panel testing & $2 / 618$ & [29] \\
\hline $\begin{array}{l}\text { FANCJ/BRIP1: } 3 \\
\text { FANCD1/BRCA2: } 2 \\
\text { FANCS/BRCA1: } 2 \\
\text { FANCU/XRCC2: } 1\end{array}$ & 189 unselected CRC patients & 25-gene NGS panel testing & $8 / 189$ & [83] \\
\hline $\begin{array}{l}\text { FANCD1/BRCA2: } 1 \\
\text { FANCN/PALB2: } 1\end{array}$ & $\begin{array}{l}88 \text { EOCRC patients } \leq 50, \\
\text { MMR-proficient }\end{array}$ & WES & $2 / 88$ & [84] \\
\hline $\begin{array}{l}\text { FANCD1/BRCA2: } 4 \\
\text { FANCJ/BRIP1: } 1 \\
\text { FANCO/RAD51C: } 1\end{array}$ & 133 EOCRC patients $<55$ years & WES & $6 / 133$ & [89] \\
\hline $\begin{array}{l}\text { FANCD1/BRCA2: } 2 \\
\text { FANCC: 1, FANCE: } 1 \\
\text { FANCJ/BRIP1: } 1\end{array}$ & $\begin{array}{l}74 \text { CRC patients from } 40 \\
\text { unrelated families with strong } \\
\text { CRC aggregation; no mutations } \\
\text { in known CRC genes }\end{array}$ & WES & $5 / 74$ & [28] \\
\hline FANCM: 4 & $\begin{array}{l}94 \text { CRC patients } \\
\text { (47 CRC-affected cousin pairs) }\end{array}$ & WES & $4 / 94$ & [96] \\
\hline $\begin{array}{l}\text { FANCA: } 1 \\
\text { FANCD1/BRCA2: } 1 \\
\text { FANCD2: 1, FANCM: } 2\end{array}$ & 141 unselected CRC patients & WES & $5 / 141$ & [31] \\
\hline
\end{tabular}

N: number of patients; CRC: colorectal cancer; EOCRC: early-onset CRC (patients age $\leq 50)$; mCRC: metastatic CRC; FCCTX: familial CRC type X (Lynch syndrome without mutations in MMR genes); MMR: mismatch repair; NGS: next-generation sequencing; WES: whole-exome sequencing.

Moreover, recent data have also suggested that pathogenic mutations in FANCN/PALB2, another established breast cancer predisposition gene, might also confer increased susceptibility to CRC [27,30,72,84]. For instance, a valuable study by AlDubayan et al. [72] evaluated the accumulation of germline FANCN/PALB2 PVs among 680 CRC patients from two independent cohorts. To verify the findings of the study, they used the germline data of 1661 unselected CRC individuals, as well as 1456 early-onset CRC patients (age < 56 years). Their findings disclosed a significant enrichment $(0.44 \%)$ of germline FANCN/PALB2 PVs in three out of 680 unselected CRC patients versus the cancer-free control population. The enrichment was also verified in 1661 unselected CRC patients from the validation cohort (five individuals $(0.3 \%)$ ). On the other hand, the study failed to confirm a higher prevalence of PALB2 PVs among 1456 early-onset CRC patients. This latter observation suggests that mutations in this gene predominantly cause late-onset CRC [72]. Nevertheless, Pearlman et al. [30] reported two positive individuals harboring PVs in FANCN/PALB2 in a cohort of 450 early-onset CRC patients. Like FANCJ/BRIP1, PVs in FANCN/PALB2 in CRC patients 
are moderately rare. Therefore, further investigations are needed to confirm the association of FANCN/PALB2 mutations with the increased risk of CRC.

Likewise, next-generation sequencing studies manifest that harboring germline heterogenic mutations in other FANC genes may also confer increased susceptibility to CRC development. In this regard, exome sequencing studies have indicated that germline monoallelic mutations in FANCC, FANCE [28], FANCM [32,96], and FANCA [31] confer susceptibility to familial CRC (see Table 1). Alternatively, multigene panel testing studies highlighted that germline mutations in FANCQ, FANCI, FANCL, FANCU, FANCO, and FANCD2 are likely linked with the increased incidence of metastatic CRC [44]. Nonetheless, it must be noted that, among the available studies, there are significant variations in the ratio of patients harboring even the same mutation. This occurrence might be due to the various methodological approaches used (e.g., PCR, arrays, different NGS platforms) and the consequent number of genes analyzed (e.g., candidate mutation screenings, panels including a variable number of genes, whole-exome sequencing) as well as to ethnic differences since several studies include mainly European populations [27,28,30,31,72,73,83,85-89,96], whereas some others considered Asian populations $[29,44,84]$. A summary of the associations between germline variations in FANC genes and CRC is presented in Table 1. However, further investigations are required to reach statistical significance at the population level and confirm the association of $F A N C$ genes with the increased risk of CRC development.

\subsection{Somatic Mutations}

Beyond germline mutations, somatically mutated FANC genes are frequently spotted in different cancerous tissue samples. An overview of cases in the NIH Genomic Data Commons (GDC) data portal has displayed that over 65\% of tumors (without regards to tissue origin) harbor at least one mutation (any type) in one of the FANC genes [14]. However, the type of mutations (e.g., gain/loss of function mutations, deletions, amplifications) and their frequency vary widely among the FANC genes. Overall, according to the analysis of 395 primary CRC samples from TGCA projects, mutated FANC genes were detected in 139 tumor samples (35.2\%) (Figure 3). In addition, the proportion of genetic alterations in FANC genes varied in such CRC samples in agreement with findings reported in other tumors [25]. For example, a wider analysis performed in a high number of patients (i.e., 3407 tumors of different origins) showed that most of the FA/HR components (e.g., FANCS/BRCA1 FANCN/PALB2, FANCD1/BRCA2) were more subjected to deletions and loss-of-function mutations, whereas the FA core complex (i.e., FANCL and FANCT /UBE2T) was predominantly affected by amplifications [25]. Intriguingly, the type of mutation probably has different functional and therapeutic consequences [25]. While somatic deletions and loss-of-function mutations in FANC genes are responsible for cancer transformation and progression, concurrently, they can provide sensitivity to DNA-damaging therapies $[17,25]$. A post-hoc analysis of metastatic CRC patients $(n=520)$ enrolled in the CALGB (Alliance)/SWOG 80,405 randomized phase III trial, performed by a next-generation sequencing approach, showed that patients treated with cytotoxic agents (i.e., FOLFOX or FOLFIRI) plus cetuximab, whose tumors harbored mutated FANCD2, had a worse overall survival compared with patients with wild-type FANCD2 tumors [97]. Such observed worse outcome may be in keeping with the fact that, among the 22 FANC genes, $F A N C D 2$ and $F A N C D 1 / B R C A 2$ are classified as mutated cancer driver genes in CRC according to the IntoGen Compendium [98].

Overall, the knowledge of germline and somatic mutations has provided a new opportunity to develop appropriate screening guidelines and deliver proper treatment approaches. The information regarding FANC gene mutations might, in fact, result in a personalized plan for cancer prevention and early detection through offering novel diagnostic, prognostic, and predictive biomarkers [5,31,95]. 
A
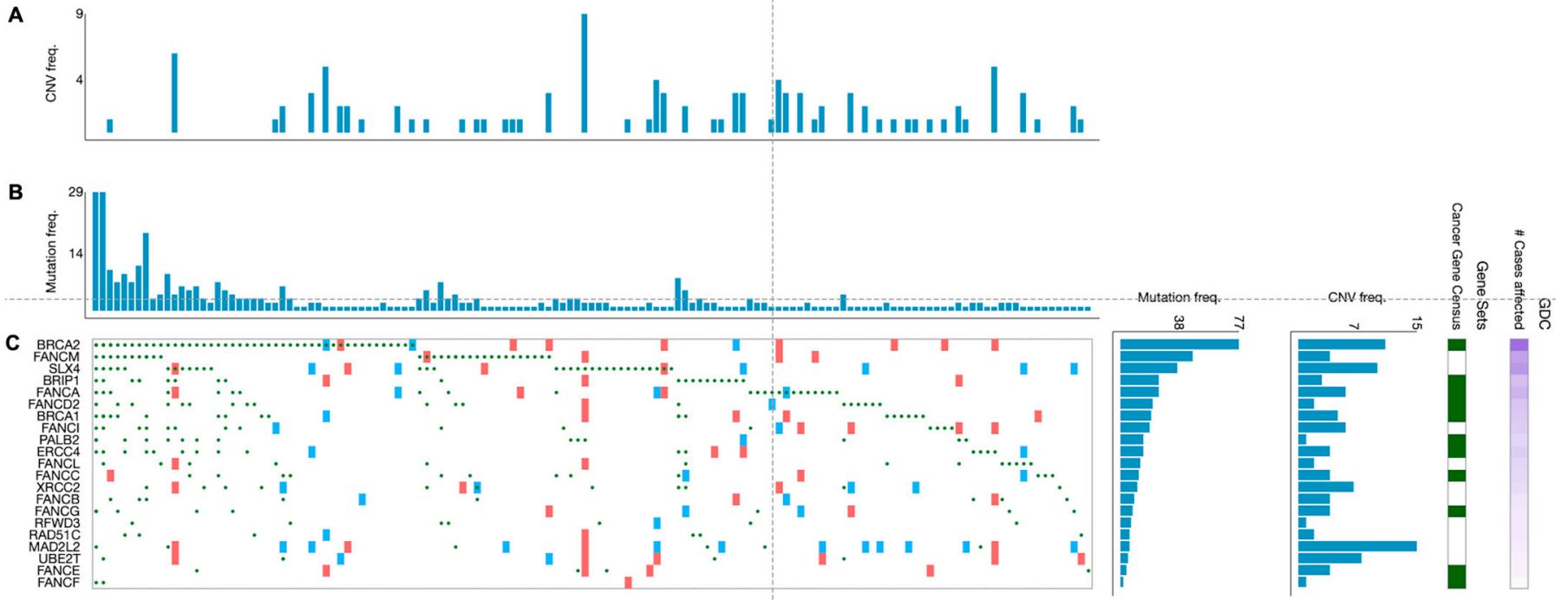

Figure 3. Genetic alterations of the FA genes in primary CRC specimens. Graphics show 139 primary CRC specimens displaying FANC gene mutations from a cohort of 395 cases. (A) Frequency of copy number variations and (B) frequency of mutations per tumor specimen. (C) Type of alterations per gene and per tumor specimen (green circles: missense, frameshift, start lost, stop lost, stop gained mutations; red squares: copy number variation (CNV) change, gain; blue squares: CNV change, loss). Data are from the TGCA program and have been generated from the GDC Data Portal [99].

\section{FA Components as Potential Biomarkers for Predicting Disease Progression and Treatment Response}

As discussed in Section 2.1, the FA pathway plays a crucial function in DNA DSB repair via HR. Alternatively, ionizing radiation [100] and DNA inter-strand crosslinking agents such as oxaliplatin and cisplatin prevent cell division and growth, principally by inducing DNA DSBs [14,101,102]. Based on these and other findings [103,104], it can be proposed that FA components in cancer cells play a critical role in the cellular capacity to repair DNA damages and chemo/radiotherapy response.

Recently, several studies have evaluated whether FA components can be served as potential biomarkers to either predict disease progression, govern treatment approaches, or offer novel targets for precision medicine [45,100,103-108]. In this regard, a recent study has evaluated the FANCT/UBE2T protein levels in $50 \mathrm{CRC}$ biopsies compared to paired noncancerous mucosa from patients who did not receive radiotherapy or chemotherapy before surgery. The outcomes showed that the levels of FANCT protein in CRC specimens were higher than in paired noncancerous tissue. Likewise, tumor tissue samples with high FANCT protein expression were associated with advanced N staging, TNM staging, and worse overall survival compared to specimens with low UBE2T protein expression [106]. A further study confirmed these findings in 30 surgically resected CRC tumor samples compared with the adjacent colonic mucosa. Considering that only 10 out of 30 of these tumors were metastatic, it is conceivable that most of the tumor tissues analyzed did not receive chemotherapy before surgery. The study showed that higher FANCT tumor mRNA expression levels predicted a worse 5-year overall survival, and high FANCT tumor protein expression levels were associated with poor differentiation, as well as worse $\mathrm{T}$ and $\mathrm{N}$ classification [105]. In vitro results from this study also pointed out that the overexpression of FANCT enhanced p53 ubiquitination and degradation, while the knockdown of FANCT increased the apoptosis induction and reduced cell migration by decreasing the N-cadherin levels [105]. Considering the crucial function of FANCT/UBE2T in inter-strand crosslink repair through monoubiquitination and activation of the ID2 complex [109], these observations offer novel insights into UBE2T as a promising prognostic biomarker for CRC. 
Moreover, several studies have reported that the FA components transform CRC progression from localized to migrative disease $[45,104,106,107]$. In this respect, the FANCD2 mRNA expression levels have been evaluated in CRC samples from 133 patients collected at the surgery. Distant metastases were present in $18 \%$ of patients. The classification of tumor specimens according to the FANCD2 expression levels indicated that tumor samples with high FANCD2 mRNA levels were associated with worse 5-year overall survival, along with the increased likelihood of either lymph node metastasis or liver metastasis development [45]. Up-regulation of FANCD2 at both mRNA and protein levels was also found in 56 CRC tumor samples compared with paired noncancerous colonic mucosa and was significantly correlated with the increased incidence of lymph node metastasis and a more advanced stage. Moreover, positive expression of FANCD2 protein was associated with worse 5-year overall survival [110]. These data suggest that FANCD2 might be a valuable biomarker for CRC treatment management and its progression monitoring.

FANCU/XRCC2 mRNA and protein levels have been evaluated in a cohort of CRC patients whose bioptic tumor samples were collected prior to chemotherapy [107]. FANCU/XRCC2 mRNA levels were significantly higher in CRC tissues compared with normal tissues. In the same study, in a second cohort of CRC patients, FANCU/XRCC2-positivity was found to be associated with a more advanced tumor stage and the increased incidence of either liver or lymph node metastasis [107]. Nevertheless, positive FANCU/XRCC2 protein expression predicted a smaller tumor size [107]. In addition, tumor FANCU/XRCC2-positivity correlated with a significantly poor response to 5-fluorouracil-based chemotherapy in terms of histological tumor regression grade [107]. This result found a counterpart in the in vitro phase of this study in which the knockdown of XRCC2 in the SW480 human CRC cell line reversed 5-fluorouracil resistance by promoting the induction of apoptosis [107].

In a further study, FANCU / XRCC2 protein levels have been evaluated in tumor tissue from locally advanced rectal cancer (LARC) patients who did not undergo radiotherapy prior to surgery [100]. The study results showed that FANCU/XRCC2-positivity was significantly associated with advanced TNM staging. Moreover, FANCU/XRCC2 protein levels were directly correlated with radioresistance in LARC patients. Interestingly, also in this case, the authors showed that the knockdown of the FANCU sensitized SW480 human CRC cells to radiotherapy via impairing DNA DSB repair [100]. Since drug resistance can arise from HR renovation [43], FANCU/XRCC2 as a crucial player in DNA DSB repair by HR might represent a valuable prognostic biomarker and predictive indicator of drug response in CRC [107] and LARC [100] patients.

Moreover, levels of FANCR/RAD51 mRNA were analyzed among $48 \mathrm{CRC}$ patients who underwent surgery without preoperative chemo/radiotherapy. The study results showed up to a 2.5-fold increase in RAD51 mRNA levels in tumor samples compared to paired noncancerous tissue. The overexpression highlighted a correlation with advanced $\mathrm{T}$ staging [111]. Although this study failed to find relationships between overexpression of RAD51 mRNA and disease progression, another study, by comparing the FANCR/RAD51 protein expression in bioptic tumor specimens from $1213 \mathrm{CRC}$ patients, has revealed that high RAD51 protein levels predicted shorter overall survival compared with lower RAD51 expression (median overall survival 11 months versus 76 months, respectively) [108]. Ihara et al. [104] investigated the potential role of the expression levels of RAD51 protein in the prediction of response to oxaliplatin-based chemotherapy in unresectable CRC patients. Their results showed that high FANCR/RAD51 expression was correlated with worse progression-free survival [104]. Moreover, some in vitro studies have shown that an increase in RAD51 expression stimulated HR, leading to higher cellular resistance to the treatment with crosslinking agents or irradiation [112,113]. These results suggest that the expression level of FANCR/RAD51, as a crucial factor in HR repair, could represent a potential prognostic and predictive biomarker in CRC.

A further study investigated FANCJ/BRIP1 mRNA and protein levels in 219 CRC samples and paired noncancerous mucosa of patients who underwent surgery before receiving chemotherapy [103]. According to immunohistochemical staining, FANCJ/BRIP1 
tumor expression levels were higher than those detected in normal mucosa. Moreover, high FANCJ/BRIP1 tumor expression levels were associated with tumor depth, worse 5-year recurrence-free survival, and more importantly, resistance to 5-fluorouracil. In terms of tumor resistance, elevated FANCJ/BRIP1 expression was connected to enhanced insensitivity, particularly in tumors with proficient MLH1 expression and not in MLH1-deficient tumors. The in vitro analysis in this study reproduced similar findings, underlining that high expression levels of FANCJ/BRIP1 conferred 5-fluorouracil resistance to MLH1-proficient cells [103]. A possible explanation for this finding is that the physical interaction between FANCJ/BRIP1 and MLH1 is critical for FANCJ/BRIP1 localization to sites of either interstrand crosslinks or DSB lesions. Indeed FANCJ-MLH1 interaction is required for cells to overcome the toxic effects of 5-fluorouracil. Thus, in the absence of MLH1, FANCJ/BRIP1 up-regulation cannot overtake inter-strand crosslinks [114]. These results are suggestive of the possibility that differential expression of FANCJ/BRIP1 might serve as a predictive biomarker to drive personalized treatment strategies.

Overall, the above reported studies showed a poor prognosis in patients whose CRC expressed high mRNA or protein levels of FANC genes. These studies analyzed tumor specimens that, according to available information, did not receive preoperative chemotherapy. Thus, it is conceivable that high FANC transcript/protein levels may contribute to critical processes such as the increased DNA damage and genomic instability independently of the treatment with radiotherapy or chemotherapy.

Conversely, low BRCA1 or BRCA2 mRNA/protein expression levels have been substantially associated with poor prognosis in CRC [115-118]. A recent study that retrieved information from The Cancer Genome Atlas (TCGA) and other databases containing CRC patients has revealed an association between BRCA1 mRNA-low tumor expression and worse clinicopathological features, including a higher proportion of advanced lymph node stages (N1/N2), a higher frequency of mucinous adenocarcinomas in conjunction with poor 5-year overall survival compared to the BRCA1 mRNA-high expression group [116]. Similarly, one previous investigation has demonstrated that the down-regulation of BRCA1 mRNA and protein expression in $120 \mathrm{CRC}$ patients who underwent surgery without preoperative chemotherapy or radiotherapy correlated with advanced lymph node metastasis, TNM stage, shorter 5-year recurrence-free, and overall survival [117]. Wang et al. [119] evaluated BRCA1 protein expression with regards to subcellular localization. Their results showed that while low expression of cytoplasmic BRCA1 was associated with advanced TNM stage and worse overall survival, high expression of nuclear BRCA1 predicted poor outcomes in CRC patients. Beyond BRCA1, a few studies have considered the association between clinicopathological features and BRCA2 expression as an independent prognostic factor. Overall, these studies underlined that decreased BRCA2 expression in CRC was correlated with advanced TNM stage and poor differentiation, although no significant association between patient survival and BRCA2 has been reported $[119,120]$. These data suggested that BRCA1/2 might be a valuable prognostic biomarker in CRC besides its importance as a candidate to target therapy.

\section{FA Components as Promising Therapeutic Targets in CRC}

The FA pathway is a potential target in cancer treatment through two distinct strategies. The first one is the chemosensitization of tumor cells to DNA crosslinking agents such as oxaliplatin and cisplatin. The second one exploits the synthetic lethal approach to selectively target tumor cells (Figure 4) [121,122]. The concept of synthetic lethality is defined as the inhibition of two or more genes leading to cell death, while repressing each individual gene does not lead to cell death. This approach is employed when the cancer cell has an initially deleterious mutation in a specific gene whose function is compensated by the second gene. Therefore, discovering and targeting the second gene may lead to cancer cell death [123]. 


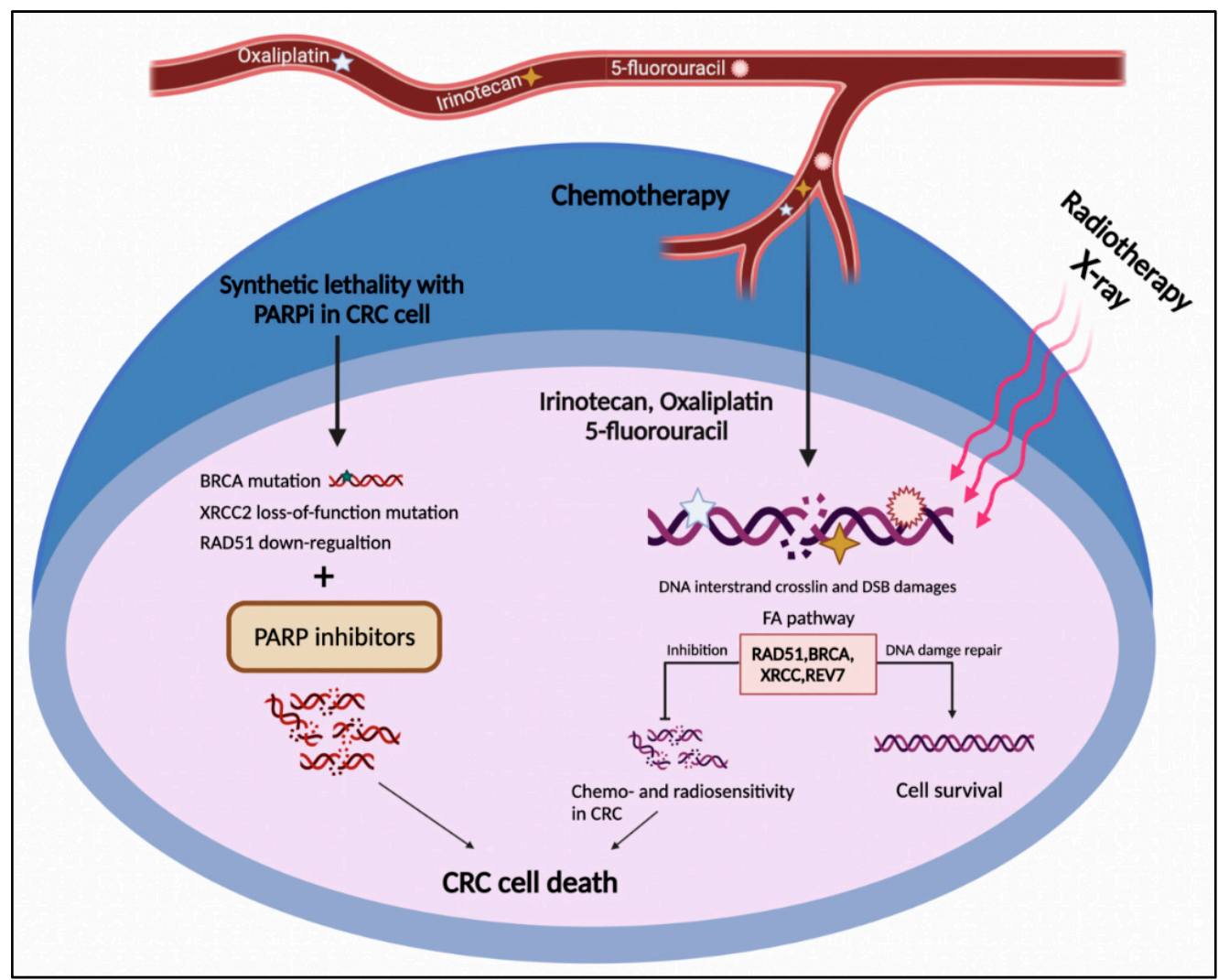

Figure 4. The FA pathway involvement in CRC treatment. The DNA damages caused by radioand chemotherapy in CRC cells result in cell death. On the other side, up-regulation of the FA pathway components such as RAD51, BRCA1/2, XRCC2, and REV7 leads to HR restoration and drug resistance. The deficiency in the FA pathway components such as BRCA1/2, XRCC2, and RAD51 represents the synthetic lethal relationship with PARP1, which might introduce druggable candidates for PARP inhibitors in CRC cells.

According to the two above-mentioned strategies, the FA pathway as a substantial part of the DNA damage response system could serve as an approaching target for CRC intervention [46]. As mentioned above, CRC cells frequently develop resistance to DNA-damaging agents through HR renovation, including the FA pathway [43]. Indeed, increased activation of the FA repair system in CRC cells might neutralize the effect of first-line chemotherapeutic agents in CRC, comprising irinotecan, oxaliplatin, and 5fluorouracil (Figure 4) [124]. As discussed in Section 2, FANC proteins not only cooperate in HR repair [125] but also contribute to replication stress tackling [126]. From a treatment perspective, although deficiencies in HR and collision in replication fork can be prominent causes of carcinogenesis, they are also promising targets for cancer treatment [127]. Emerging data have shown that targeting the components of the FA pathway not only sensitizes CRC cells to DNA-damaging agents but can also induce cell death through a synthetic lethal interaction. In this respect, FANCR/RAD51 and FANCD1/S (BRCA1/2) genes received the most consideration in the context of the therapeutic vulnerability of CRC [128].

Recent discoveries pointed out that crosstalks between BRCA1, BRCA2, and RAD51 are essential to protect nascent DNA at stalled forks [67]. Upon replication stress, RAD51, regulated by the ataxia telangiectasia and Rad3-related kinase (ATR), preserves the stalled replication fork and promotes fork restart [47]. Accordingly, checkpoint kinase 1 (CHK1) directly interplays with ATR to assist replication fork stabilization during replication stress [41]. Hence, a collection of responses to replication stress is built on the ATRCHK1 axis [129]. Increasing evidence shows that the ATR-CHK1 axis plays a crucial role in the viability of CRC cells by protecting replication forks under the condition of 
replication stress [130]. However, some CRC stem cells display resistance to ATR or CHK1 inhibitors. In such context, one study revealed that RAD51 targeting improves the vulnerability of CRC stem cells to the CHK1/2 inhibitor prexasertib and annihilates them through triggering mitotic catastrophe by the caspase-dependent mechanism [131]. Likewise, Manic et al. [129] have demonstrated that the RAD51 inhibitor B02, along with the MRE11 inhibitor mirin, selectively kills the PARP1-upregulated CRC stem cells via mitotic catastrophe without the need for exposing cells to ATR/CHK1 inhibitors [129]. In addition, a growing body of evidence shows that RAD51 up-regulation leads to PARP inhibitor (PARPI) resistance in CRC [132,133]. Regarding this, Smeby et al. [132] indicated that a subset of TP53 wild-type CRC cell lines were sensitive to the effect of PARPIs, whereas TP53 inhibition reversed the consequence. The authors of this study verified that talazoparib sensitivity in TP53 wild-type cell lines was correlated with down-regulation of FANCR/RAD51 protein expression. They highlighted a possible mechanism by which wild-type TP53 governs RAD51 suppression upon talazoparib treatment. Similarly, Arena et al. [133] showed that increased RAD51 foci formation, a functional biomarker of HR repair, was connected with resistance to the PARPI olaparib in patient-derived CRC models enriching for KRAS and BRAF mutations. In this study, the increase in RAD51 foci formation in all olaparib-resistant cells was confirmed, whereas a comparable effect was not observed in sensitive cells [133]. Regarding the association between KRAS mutations and RAD51 expression, Kalimutho et al. [134] revealed that ionizing radiations increased the generation of FANCR/RAD51 foci in the HCT116 KRAS-mutated CRC cells, compared with the wild-type counterparts. These authors showed that although KRAS mutation evokes replication stress and DNA damage accumulation, it assists cell surveillance by increasing the expression of RAD51. Consequently, they found that the co-inhibition of RAD51 and MEK1/2 signaling with the RAD51 inhibitor RI-1 and the MEK1/2 inhibitor AZD6244, respectively, induced DNA damage and apoptosis predominantly in KRASmutant cells while sparing wild-type cells. These findings support the hypothesis that the resistance of KRAS-mutant CRC cells to targeted agents can arise from the activation of compensatory pathways, particularly the HR pathway. Therefore, targeting RAD51 may offer a feasible strategy in killing KRAS-mutated CRC cells [134]. The findings of these recent works may support the candidature of the FANCR/RAD51 gene as a predictor of sensitivity to PARPIs and HR functionality [132-134].

Aside from chemotherapeutic and targeted agents, it has been highlighted that some natural flavonoids, such as alpinumisoflavone, possess suppressing effects on RAD51. Li et al. [135] found that treatment with alpinumisoflavone, which shows antioxidant, anti-inflammatory, and anti-cancer properties, significantly decreased RAD51 levels in both in vitro and in vivo CRC models. Moreover, the knockdown of RAD51 increased the anti-cancer activity of alpinumisoflavone in preclinical CRC models, while the alpinumisoflavone effect was abolished by the up-regulation of RAD51 [135].

Knowledge of the $B R C A$ status has raised hope for personalized cancer treatment by potentially adding platinum/DNA-damaging agents or PARPIs [129]. PARP is considered the potential synthetic lethal partner of $B R C A$ mutations, and its inhibitors are now FDAapproved for the treatment of $B R C A 1 / 2-$ mutated breast and ovarian cancer [136]. In addition, the FDA also approved olaparib for the treatment of metastatic castration-resistant prostate cancer patients with deleterious HR gene mutations who progressed on a previous androgen receptor signaling inhibitor treatment [137]. Several studies propose that PARPIs prompt cell death by accumulating unrepaired DSBs due to the HR deficiency in BRCAmutated cells. Even though BRCA mutations are infrequent in CRC, the PARPIs are undergoing several clinical trial investigations as single agents or combined with radiation or chemotherapeutic agents [138-144].

In this regard, Paviolo et al. [140] have shown that the treatment of BRCA-deficient CRC cell lines with olaparib may lead to genomic instability and cell death [140]. Moreover, Reisländer et al. [144] have revealed that the treatment of BRCA1- or BRCA2-deficient $\mathrm{CRC}$ cell lines with olaparib boosted the up-regulation of innate immune response genes 
upon intrinsically high levels of DNA damage [144]. Moving to the clinical setting, a phase II trial investigating the combination of the PARPI veliparib and the alkylating agent temozolomide showed good tolerability and clinical efficacy in patients with metastatic colon cancer [139]. Furthermore, the results of a phase $1 b$ study have revealed that the administration of veliparib combined with neoadjuvant capecitabine and radiotherapy has an acceptable safety profile and a dose-proportional pharmacokinetic profile in patients with LARC [138]. A randomized phase II clinical trial showed similar efficacy for veliparib plus fluorouracil, leucovorin, irinotecan (FOLFIRI), and bevacizumab compared with FOLFIRI and bevacizumab in metastatic CRC patients [141].

Regarding the microsatellite status, Williams et al. [143] showed that the combination of irinotecan with niraparib, a potent PARP1/2I, in either MSI or MSS CRC cells, synergistically enhanced the anti-tumor effects of both agents either in vitro or in vivo [143]. Thus, these data suggest that niraparib enhances the effect of irinotecan regardless of microsatellite status [143].

Focusing on synthetic lethal interactions, Tiong et al. [145] evaluated in a publicly available CRC GEO dataset the gene expression of cancerous and normal tissues to screen novel synthetic lethal interactions in metastatic CRC. They introduced the POLB and CSNK1E genes, in addition to the $M S H 2$ gene, as potential synthetic lethal partners of $B R C A 1$ and $B R C A 2$, respectively [145]. Such gene pairs (i.e., BRCA1-POLB, BRCA1-CSNK1E, and $B R C A 2-M S H 2)$ were associated with clinicopathological features (i.e., tumor size, lymph node metastasis, and metastasis, respectively [145]. A further similar analysis performed on metastatic CRC cases suggested that BRCA1 targeting might increase the prognostic and therapeutic effects of bevacizumab [146]. In addition, polymerase theta (POLQ), which is involved in the repair pathway of replication-associated lesions, is introduced as the synthetic lethal partner of DNA damage repair genes such as BRCA1/2 in various malignancies, including colon cancer. One possible mechanism to explain the synthetic lethality between $P O L Q$ and HR genes is that HR-deficient cancer cells rely on polymerase theta-mediated end joining (TMEJ) for their DNA DSB repair during replication stress [147].

As mentioned earlier, $B R C A$ mutations can also help to personalize treatment by adding platinum/DNA-damaging agents. A case report described the addition of oxaliplatin to the chemoradiation regimen before surgery in a young patient with LARC who achieved a complete pathologic response without signs of disease recurrence at follow-up. The authors pointed out that the treatment modality was designed based on the confirmed $B R C A 1$ pathogenic mutation in the patient and known sensitivity of BRCA-mutant tumors to platinum-based chemotherapy [148].

FANCU/XRCC2 is not only a potentially useful predictive biomarker of treatment responses in CRC patients, as already detailed in Section 4 [100,107], but it might also be a promising therapeutic target for the treatment of CRC [145]. In this regard, Wang et al. [149] showed that the knockdown of FANCU/XRCC2 expression in the T84 colon tumor cell line was associated with increased sensitivity to X-radiation in both in vitro and in vivo settings. The results represented XRCC2 as a potential therapeutic target for overcoming radioresistance in CRC [149]. Another study showed that the up-regulation of XRCC2 in CRC cell lines and tissue samples was correlated with the down-regulation of miR-7 [147]. Moreover, XRCC2 targeting by miR-7 could efficiently induce apoptosis and inhibit proliferation in several CRC cell lines [150]. Additionally, according to the synthetic lethality concept, tumors showing XRCC2 loss-of-function mutations could be responsive to PARP inhibition [151]. In support of this hypothesis, cells harboring the biallelic mutation of FANCU/XRCC2 showed increased sensitivity to olaparib compared to XRCC2 wild-type cells [152]. Thus, the identification of breast cancer patients and perhaps other cancer patients with deleterious somatic variants of XRCC2 may be a basis for such personalized treatments. On the contrary, in a study by Xu et al. [153], CRC cell lines with a higher expression of XRCC2 were sensitive to olaparib, in contrast with the theory of synthetic lethality. The authors claimed that one possible explanation for their finding 
was the involvement of both XRCC2 and PARP1 in the HRR pathway in which XRCC2 expression is required for the effect of olaparib [153].

FANCV/REV7, a key component of translesion synthesis polymerase zeta, can potentially be targeted to overcome CRC chemoresistance. A study by Sun et al. [154] assumed that the down-regulation of FANCV/REV7 reverted 5-fluorouracil and oxaliplatin resistance in CRC cells by impairing the translesion DNA synthesis pathway. In vitro data showed that the knockdown of FANCV/REV7 sensitized CRC cells to 5-fluorouracil and oxaliplatin, which was also confirmed in a murine xenograft model [154]. These observations suggest that FANCV/REV7 can be a promising target to overcome drug resistance by producing synergistic effects with first-line chemotherapeutic agents in CRC.

Given that drug resistance is a critical obstacle in CRC treatment, the knowledge of such mutations could allow for the proper adding of platinum/DNA-damaging agents or PARPIs in the neoadjuvant setting for each patient. However, more comprehensive investigations are required for the FANC genes targeting in the clinic. A synthesis of the above-reported studies is provided in Table 2, in which the FA components, their status, and drug treatment or synthetic lethality partners are described.

Table 2. FA components as potential therapeutic targets in CRC.

\begin{tabular}{|c|c|c|c|c|c|c|}
\hline FA Component & $\begin{array}{l}\text { FA Component } \\
\text { Status }\end{array}$ & $\begin{array}{l}\text { Drug Treatment(s) } \\
\text { or Synthetic } \\
\text { Lethality Partner(s) }\end{array}$ & Study Materials & Setting & $\begin{array}{l}\text { Mechanism of } \\
\text { Action/Observed } \\
\text { Results }\end{array}$ & Ref. \\
\hline \multirow{6}{*}{ FANCR/RAD51 } & $\begin{array}{l}\text { RAD51 inhibition } \\
\text { (B02 inhibitor) }\end{array}$ & $\begin{array}{l}\text { Prexasertib } \\
\text { (CHK1/2 inhibitors) }\end{array}$ & CRC stem cells & In vitro & $\begin{array}{l}\text { Triggering mitotic } \\
\text { catastrophe }\end{array}$ & [131] \\
\hline & $\begin{array}{l}\text { RAD51 inhibition } \\
\text { (B02 inhibitor) }\end{array}$ & $\begin{array}{l}\text { Mirin } \\
\text { (MRE11 inhibitor) }\end{array}$ & $\begin{array}{l}\text { PARP1- } \\
\text { upregulated CRC } \\
\text { stem cells }\end{array}$ & $\begin{array}{l}\text { In vitro and } \\
\text { in vivo }\end{array}$ & $\begin{array}{l}\text { Triggering mitotic } \\
\text { catastrophe }\end{array}$ & [129] \\
\hline & $\begin{array}{l}\text { Decreased RAD51 } \\
\text { protein }\end{array}$ & $\begin{array}{l}\text { Talazoparib } \\
\text { (PARP inhibitor) }\end{array}$ & $\begin{array}{l}\text { TP53 wild-type cell } \\
\text { lines }\end{array}$ & In vitro & $\begin{array}{l}\text { Increased } \\
\text { sensitivity to the } \\
\text { PARP inhibitor }\end{array}$ & [132] \\
\hline & $\begin{array}{l}\text { Increased RAD51 } \\
\text { foci formation }\end{array}$ & $\begin{array}{l}\text { Olaparib } \\
\text { (PARP inhibitor) }\end{array}$ & $\begin{array}{l}\text { Patient-derived } \\
\text { CRC models }\end{array}$ & In vitro & $\begin{array}{l}\text { Resistance to the } \\
\text { PARP inhibitor }\end{array}$ & [133] \\
\hline & $\begin{array}{l}\text { RAD51 inhibition } \\
\text { (RI-1 inhibitor) }\end{array}$ & $\begin{array}{l}\text { AZD6244 } \\
\text { (MEK1/2 inhibitor) }\end{array}$ & $K R A S$-mutant cells & In vitro & $\begin{array}{l}\text { Induction of DNA } \\
\text { damage and } \\
\text { apoptosis }\end{array}$ & [134] \\
\hline & $\begin{array}{l}\text { RAD51 knockdown } \\
\text { (specific siRNA) }\end{array}$ & $\begin{array}{l}\text { Alpinumisoflavone } \\
\text { (natural flavonoid) }\end{array}$ & CRC cell lines & In vitro & $\begin{array}{l}\text { Increased } \\
\text { anti-cancer activity } \\
\text { of } \\
\text { alpinumisoflavone }\end{array}$ & [135] \\
\hline \multirow{4}{*}{$\begin{array}{l}\text { FANCD1/S } \\
(B R C A 1 / 2)\end{array}$} & $\begin{array}{l}B R C A 1 / 2 \text { depletion } \\
\text { (specific shRNA) }\end{array}$ & $\begin{array}{l}\text { Olaparib } \\
\text { (PARP inhibitor) }\end{array}$ & $\begin{array}{l}\text { BRCA-deficient } \\
\text { cell lines }\end{array}$ & In vitro & $\begin{array}{l}\text { Genomic instability } \\
\text { and cell death }\end{array}$ & [140] \\
\hline & $\begin{array}{l}B R C A 1 / 2 \text { depletion } \\
\text { (specific shRNA) }\end{array}$ & $\begin{array}{l}\text { Olaparib and } \\
\text { talazoparib } \\
\text { (PARP inhibitors) }\end{array}$ & $\begin{array}{l}\text { BRCA-deficient } \\
\text { cell lines }\end{array}$ & $\begin{array}{l}\text { In vitro and } \\
\text { in vivo }\end{array}$ & $\begin{array}{l}\text { Elicit innate } \\
\text { immune response }\end{array}$ & [144] \\
\hline & ND & $\begin{array}{l}\text { Niraparib } \\
\text { (PARP inhibitor) } \\
\text { and irinotecan }\end{array}$ & $\begin{array}{l}\text { MSI or MSS } \\
\text { CRC cells }\end{array}$ & $\begin{array}{l}\text { In vitro or } \\
\text { in vivo }\end{array}$ & $\begin{array}{l}\text { Enhancement of the } \\
\text { anti-tumor effects } \\
\text { of both agents }\end{array}$ & [143] \\
\hline & $\begin{array}{l}B R C A 1 \\
\text { gene expression }\end{array}$ & $\begin{array}{l}\text { POLB, } \\
\text { CSNK1E, MSH2 }\end{array}$ & $\begin{array}{l}\text { GEO } \\
\text { datasets-mCRC } \\
\text { patients and } \\
\text { CRC cells }\end{array}$ & $\begin{array}{l}\text { Translational } \\
\text { and in vitro }\end{array}$ & Synthetic lethality & [145] \\
\hline
\end{tabular}


Table 2. Cont.

\begin{tabular}{|c|c|c|c|c|c|c|}
\hline FA Component & $\begin{array}{l}\text { FA Component } \\
\text { Status }\end{array}$ & $\begin{array}{l}\text { Drug Treatment(s) } \\
\text { or Synthetic } \\
\text { Lethality Partner(s) }\end{array}$ & Study Materials & Setting & $\begin{array}{l}\text { Mechanism of } \\
\text { Action/Observed } \\
\text { Results }\end{array}$ & Ref. \\
\hline & $\begin{array}{l}B R C A 2 \\
\text { gene expression }\end{array}$ & MSH2 & $\begin{array}{l}\text { GEO } \\
\text { datasets-mCRC } \\
\text { patients and } \\
\text { CRC cells }\end{array}$ & $\begin{array}{l}\text { Translational } \\
\text { and in vitro }\end{array}$ & Synthetic lethality & [145] \\
\hline & $\begin{array}{l}\text { High } B R C A 1 \\
\text { gene expression }\end{array}$ & $\begin{array}{l}\text { Bevacizumab } \\
\text { (VEGF Inhibitor) }\end{array}$ & $\begin{array}{l}\text { GEO datasets- } \\
\text { mCRC patients }\end{array}$ & Translational & $\begin{array}{l}\text { More } \\
\text { favourable PFS }\end{array}$ & [146] \\
\hline & Mutated $B R C A 1$ & $\begin{array}{l}\text { Oxaliplatin plus } \\
\text { radiation } \\
\text { before surgery }\end{array}$ & One LARC patient & Case report & $\begin{array}{l}\text { Increased } \\
\text { sensitivity to } \\
\text { platinum-based } \\
\text { chemotherapy }\end{array}$ & [148] \\
\hline \multirow{4}{*}{ FANCU/XRCC2 } & $\begin{array}{l}\text { XRCC2 depletion } \\
\text { (specific shRNA) }\end{array}$ & X-radiation & $\begin{array}{l}\text { T84 colon tumor } \\
\text { cell line }\end{array}$ & $\begin{array}{l}\text { In vitro and } \\
\text { In vivo }\end{array}$ & $\begin{array}{l}\text { Increased } \\
\text { sensitivity to } \\
\text { X-radiation }\end{array}$ & [149] \\
\hline & $\begin{array}{l}\text { XRCC2 targeting } \\
\text { by miR-7 }\end{array}$ & - & CRC cell lines & In vitro & $\begin{array}{l}\text { Apoptosis and } \\
\text { inhibition of } \\
\text { proliferation }\end{array}$ & [151] \\
\hline & $\begin{array}{l}\text { Biallelic } \\
\text { mutated XRCC2 }\end{array}$ & $\begin{array}{l}\text { Olaparib } \\
\text { (PARP inhibitor) }\end{array}$ & Fibroblast cells & In vitro & $\begin{array}{l}\text { Increased } \\
\text { sensitivity to } \\
\text { olaparib }\end{array}$ & [152] \\
\hline & $\begin{array}{l}\text { Increased } \\
\text { expression } \\
\text { of XRCC2 }\end{array}$ & $\begin{array}{l}\text { Olaparib } \\
\text { (PARP inhibitor) }\end{array}$ & CRC cell lines & In vitro & Synthetic lethality & [153] \\
\hline FANCV/REV7 & $\begin{array}{l}\text { REV7 depletion } \\
\text { (CRISPR/Cas9) }\end{array}$ & $\begin{array}{l}\text { 5-fluorouracil } \\
\text { and oxaliplatin }\end{array}$ & CRC cells & $\begin{array}{l}\text { In vitro and } \\
\text { In vivo }\end{array}$ & $\begin{array}{l}\text { Impair of } \\
\text { translesion DNA } \\
\text { synthesis pathway }\end{array}$ & [154] \\
\hline
\end{tabular}

$\mathrm{ND}$, not determined; CRC, colorectal cancer; LARC, locally advancer rectal cancer; GEO, Gene Expression Omnibus; PFS, progression-free survival

\section{Conclusions}

The best intention of this review was to highlight the importance of FANC genes as potent predisposing risk factors to CRC and their potential applications in future clinical practice. Available data suggest that FANC genes could be used in CRC management as potential biomarkers for early diagnosis, evaluating prognostic outcomes, monitoring therapy response, modifying treatment plans, and selecting effective therapeutic agents.

Author Contributions: Conceptualization, F.G.P. and E.N.-M.; methodology, F.G.P. and E.N.-M.; software, F.G.P.; validation, S.N., H.A.A. and E.M.; writing-original draft preparation, F.G.P. and M.K.; writing-review and editing, F.G.P., S.N., E.N.-M. and E.M.; visualization, F.G.P., M.K. and H.A.A.; supervision, E.N.-M., S.N. and E.M.; project administration, E.N.-M. and E.M. All authors have read and agreed to the published version of the manuscript.

Funding: This research was partially supported by Fondo Beneficenza Intesa Sanpaolo S.p.A. (Milan, Italy) to E.M.

Institutional Review Board Statement: Not applicable.

Informed Consent Statement: Not applicable.

Data Availability Statement: Not applicable.

Conflicts of Interest: The authors declare no conflict of interest. 
Abbreviations

APC

ATR

BCDX2 complex

BMPR1A

BRAF

BRCA

BRCA2

BRIP1

CHK1

$\mathrm{CNV}$

CRC

dNTP

DSB

EOCRC

ERCC1

ERCC4

FA

FAAP

FAAP100

FAAP20

FAAP24

FAN1

FANC

FANCA

FANCB

FANCC

FANCD1

FANCD2

FANCE

FANCF

FANCG

FANCI

FANCJ

FANCL

FANCM

FANCN

FANCO

FANCP

FANCQ

FANCR

FANCS

FANCT

FANCU

FANCV

FANCW

FCCTX

FOLFIRI

FOLFOX

G4

GEO

HR
APC regulator of WNT signaling pathway

ataxia telangiectasia and RAd3-related kinase

RAD51 paralogs (RAD51B, RAD51C, RAD51D) and XRCC2

bone morphogenetic protein receptor type $1 \mathrm{~A}$

B-Raf proto-oncogene, serine/threonine kinase

BRCA1 DNA repair associated (alias FANCS)

BRCA2 DNA repair associated (alias FANCD, FANCD1)

BRCA1 interacting helicase 1 (alias FANCJ)

checkpoint kinase1

copy number variation

colorectal cancer

deoxyribonucleoside triphosphate

double-strand break

early-onset CRC

ERCC excision repair 1, endonuclease catalytic subunit

ERCC excision repair 4, endonuclease catalytic subunit (alias FANCQ)

Fanconi anemia

RNA $2^{\prime}, 3^{\prime}$-cyclic phosphate and $5^{\prime}-\mathrm{OH}$ ligase

FA core complex associated protein 100

FA core complex associated protein 20

FA core complex associated protein 24

FANCD2 and FANCI associated nuclease 1

FA complementation group

FA complementation group A

FA complementation group B

FA complementation group $C$

BRCA2 DNA repair associated (official symbol BRCA2)

FA complementation group D2

FA complementation group $\mathrm{E}$

FA complementation group $\mathrm{F}$

FA complementation group G (alias XRCC9)

FA complementation group I

BRCA1 interacting helicase 1 (official symbol BRIP1)

FA complementation group $\mathrm{L}$

FA complementation group $\mathrm{M}$

partner and localizer of BRCA2 (official symbol PALB2)

RAD51 paralog C (official symbol RAD51C)

SLX4 structure-specific endonuclease subunit

ERCC excision repair 4, endonuclease catalytic subunit (official symbol ERCC4)

RAD51 recombinase (official symbol RAD51)

BRCA1 DNA repair associated (official symbol BRCA)

FA complementation group T/Ubiquitin Conjugating Enzyme E2 T

(official symbol UBE2T)

X-ray repair cross complementing 2 (official symbol XRCC2)

mitotic arrest deficient 2 like 2 (official symbol: MAD2L2; alias REV7)

ring finger and WD repeat domain 3 (official symbol RFWD3)

familial CRC type $X$

fluorouracil/leucovorin, irinotecan

fluorouracil/leucovorin, oxaliplatin

G-quadruplex

Gene Expression Omnibus

homologous recombination 


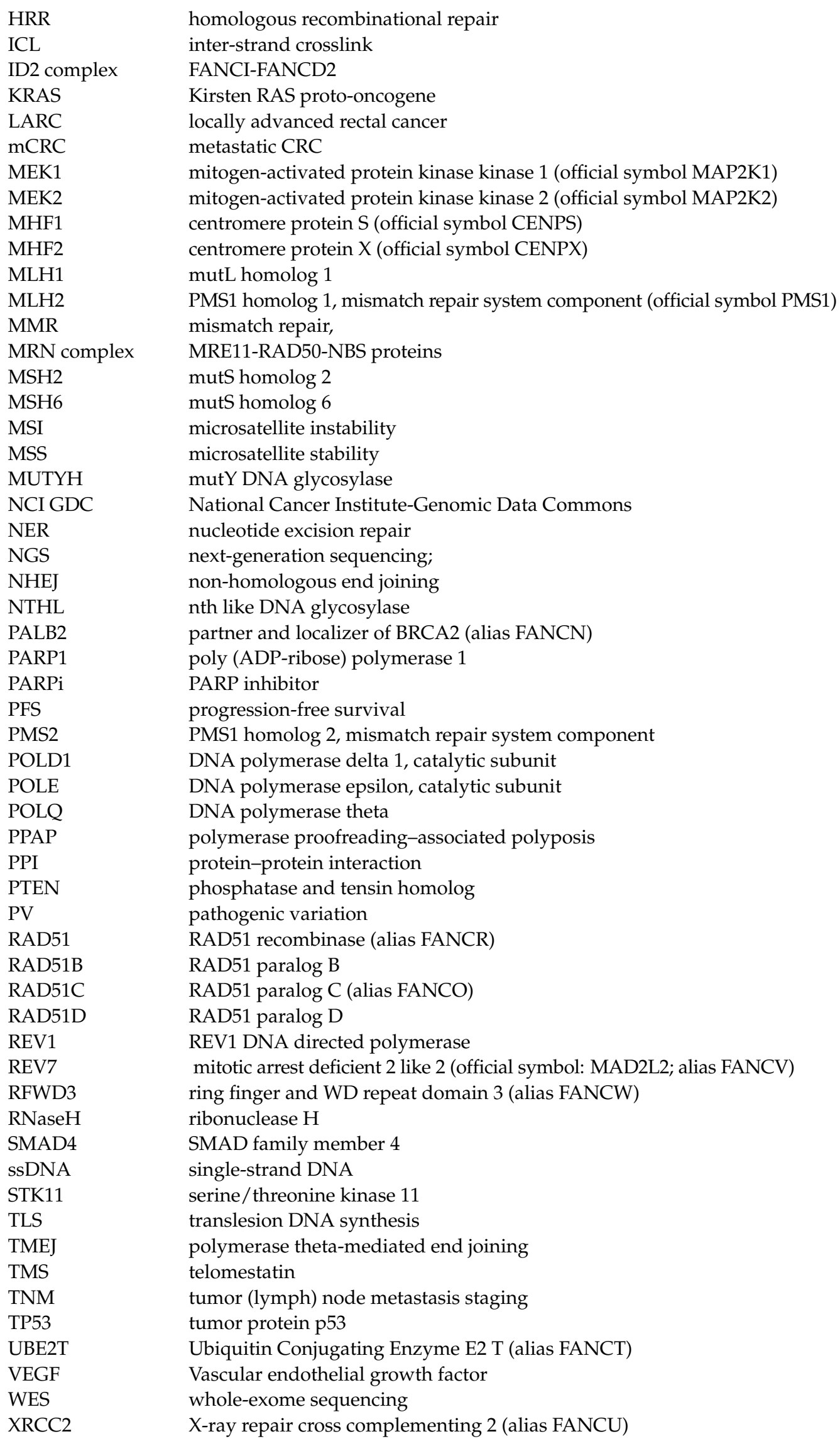




\section{References}

1. Sung, H.; Ferlay, J.; Siegel, R.L.; Laversanne, M.; Soerjomataram, I.; Jemal, A.; Bray, F. Global Cancer Statistics 2020: GLOBOCAN Estimates of Incidence and Mortality Worldwide for 36 Cancers in 185 Countries. CA Cancer J. Clin. 2021, 71, 209-249. [CrossRef]

2. Rustgi, A.K. The genetics of hereditary colon cancer. Genes Dev. 2007, 21, 2525-2538. [CrossRef] [PubMed]

3. Weiss, J.M.; Gupta, S.; Burke, C.A.; Axell, L.; Chen, L.-M.; Chung, D.C.; Clayback, K.M.; Dallas, S.; Felder, S.; Gbolahan, O.; et al. NCCN Guidelines ${ }^{\circledR}$ Insights: Genetic/Familial High-Risk Assessment: Colorectal.; Version 1.2021: Featured Updates to the NCCN Guidelines. J. Natl. Compr. Cancer Netw. 2021, 19, 1122-1132. [CrossRef]

4. Weren, R.D.; Ligtenberg, M.J.; Kets, C.M.; De Voer, R.M.; Verwiel, E.T.; Spruijt, L.; van Zelst-Stams, W.A.; Jongmans, M.C.; Gilissen, C.; Hehir-Kwa, J.Y.; et al. A germline homozygous mutation in the base-excision repair gene NTHL1 causes adenomatous polyposis and colorectal cancer. Nat. Genet. 2015, 47, 668-671. [CrossRef] [PubMed]

5. Valle, L.; de Voer, R.M.; Goldberg, Y.; Sjursen, W.; Försti, A.; Ruiz-Ponte, C.; Caldés, T.; Garré, P.; Olsen, M.F.; Nordling, M.; et al. Update on genetic predisposition to colorectal cancer and polyposis. Mol. Asp. Med. 2019, 69, 10-26. [CrossRef] [PubMed]

6. Esteban-Jurado, C.; Giménez-Zaragoza, D.; Muñoz, J.; Franch-Expósito, S.; Álvarez-Barona, M.; Ocaña, T.; Cuatrecasas, M.; Carballal, S.; López-Cerón, M.; Marti-Solano, M.; et al. POLE and POLD1 screening in 155 patients with multiple polyps and early-onset colorectal cancer. Oncotarget 2017, 8, 26732-26743. [CrossRef]

7. Church, J.M. Polymerase Proofreading-Associated Polyposis: A new, dominantly inherited syndrome of hereditary colorectal cancer predisposition. Dis. Colon Rectum 2014, 57, 396-397. [CrossRef]

8. Magrin, L.; Fanale, D.; Brando, C.; Fiorino, A.; Corsini, L.R.; Sciacchitano, R.; Filorizzo, C.; Dimino, A.; Russo, A.; Bazan, V. POLE, POLD1, and NTHL1: The last but not the least hereditary cancer-predisposing genes. Oncogene 2021, 40, 5893-5901. [CrossRef]

9. Mur, P.; García-Mulero, S.; del Valle, J.; Magraner-Pardo, L.; Vidal, A.; Pineda, M.; Cinnirella, G.; Martín-Ramos, E.; Pons, T.; López-Doriga, A.; et al. Role of POLE and POLD1 in familial cancer. Genet. Med. 2020, 22, 2089-2100. [CrossRef]

10. Mankaney, G.; Rouphael, C.; Burke, C.A. Serrated Polyposis Syndrome. Clin. Gastroenterol. Hepatol. 2020, 18, 777-779. [CrossRef]

11. Velázquez, C.; Lastra, E.; Cobos, F.A.; Abella, L.; De La Cruz, V.; Hernando, B.A.; Hernández, L.; Martínez, N.; Infante, M.; Durán, M. A comprehensive custom panel evaluation for routine hereditary cancer testing: Improving the yield of germline mutation detection. J. Transl. Med. 2020, 18, 232. [CrossRef] [PubMed]

12. Boussios, S.; Ozturk, M.A.; Moschetta, M.; Karathanasi, A.; Zakynthinakis-Kyriakou, N.; Katsanos, K.H.; Christodoulou, D.K.; Pavlidis, N. The Developing Story of Predictive Biomarkers in Colorectal Cancer. J. Pers. Med. 2019, 9, 12. [CrossRef] [PubMed]

13. Mini, E.; Landini, I.; Di Paolo, A.; Ravegnini, G.; Saponara, S.; Frosini, M.; Lapucci, A.; Nobili, S. Predictive 'Omic' biomarkers of drug response: Colorectal cancer as a model. In Anti-Angiogenic Drugs as Chemosensitizers in Cancer Therapy; Cancer Sensitizing Agents for Chemotherapy Series; Morbidelli, L., Ed.; Academic Press (Elsevier): London, UK, 2022; Volume 18, pp. 199-240.

14. Liu, W.; Palovcak, A.; Li, F.; Zafar, A.; Yuan, F.; Zhang, Y. Fanconi anemia pathway as a prospective target for cancer intervention. Cell Biosci. 2020, 10, 39. [CrossRef] [PubMed]

15. Kolinjivadi, A.M.; Crismani, W.; Ngeow, J. Emerging functions of Fanconi anemia genes in replication fork protection pathways. Hum. Mol. Genet. 2020, 29, R158-R164. [CrossRef]

16. Woodward, E.R.; Meyer, S. Fanconi Anaemia, Childhood Cancer and the BRCA Genes. Genes 2021, 12, 1520. [CrossRef]

17. Nalepa, G.; Clapp, D.W. Fanconi anaemia and cancer: An intricate relationship. Nat. Rev. Cancer 2018, 18, 168-185. [CrossRef]

18. Nepal, M.; Che, R.; Zhang, J.; Ma, C.; Fei, P. Fanconi anemia Signaling and Cancer. Trends Cancer 2017, 3, 840-856. [CrossRef]

19. Michl, J.; Zimmer, J.; Tarsounas, M. Interplay between Fanconi anemia and homologous recombination pathways in genome integrity. EMBO J. 2016, 35, 909-923. [CrossRef]

20. Howlett, N.G.; Taniguchi, T.; Olson, S.; Cox, B.; Waisfisz, Q.; De Die-Smulders, C.; Persky, N.; Grompe, M.; Joenje, H.; Pals, G.; et al. Biallelic Inactivation of BRCA2 in Fanconi anemia. Science 2002, 297, 606-609. [CrossRef]

21. Milletti, G.; Strocchio, L.; Pagliara, D.; Girardi, K.; Carta, R.; Mastronuzzi, A.; Locatelli, F.; Nazio, F. Canonical and Noncanonical Roles of Fanconi anemia Proteins: Implications in Cancer Predisposition. Cancers 2020, 12, 2684. [CrossRef] [PubMed]

22. Risinger, M.A.; Groden, J. Crosslinks and crosstalk: Human cancer syndromes and DNA repair defects. Cancer Cell 2004, 6, 539-545. [CrossRef] [PubMed]

23. Fang, C.-B.; Wu, H.-T.; Zhang, M.-L.; Liu, J.; Zhang, G.-J. Fanconi anemia Pathway: Mechanisms of Breast Cancer Predisposition Development and Potential Therapeutic Targets. Front. Cell Dev. Biol. 2020, 8, 160. [CrossRef] [PubMed]

24. Chan, S.H.; Ni, Y.; Li, S.-T.; Teo, J.X.; Ishak, N.D.B.; Lim, W.K.; Ngeow, J. Spectrum of Germline Mutations within Fanconi anemia-Associated Genes Across Populations of Varying Ancestry. JNCI Cancer Spectr. 2021, 5, pkaa117. [CrossRef]

25. Niraj, J.; Färkkilä, A.; D’Andrea, A.D. The Fanconi anemia Pathway in Cancer. Annu. Rev. Cancer Biol. 2019, 3, 457-478. [CrossRef]

26. Boussios, S.; Mikropoulos, C.; Samartzis, E.; Karihtala, P.; Moschetta, M.; Sheriff, M.; Karathanasi, A.; Sadauskaite, A.; Rassy, E.; Pavlidis, N. Wise Management of Ovarian Cancer: On the Cutting Edge. J. Pers. Med. 2020, 10, 41. [CrossRef]

27. Yurgelun, M.B.; Kulke, M.H.; Fuchs, C.S.; Allen, B.A.; Uno, H.; Hornick, J.; Ukaegbu, C.I.; Brais, L.K.; McNamara, P.G.; Mayer, R.J.; et al. Cancer Susceptibility Gene Mutations in Individuals with Colorectal Cancer. J. Clin. Oncol. 2017, 35, 1086-1095. [CrossRef] 
28. Esteban-Jurado, C.; Franch-Expósito, S.; Muñoz, J.; Ocaña, T.; Carballal, S.; López-Cerón, M.; Cuatrecasas, M.; Vila-Casadesús, M.; Lozano, J.J.; Serra, E.; et al. The Fanconi anemia DNA damage repair pathway in the spotlight for germline predisposition to colorectal cancer. Eur. J. Hum. Genet. 2016, 24, 1501-1505. [CrossRef]

29. Gong, R.; He, Y.; Liu, X.-Y.; Wang, H.-Y.; Sun, L.-Y.; Yang, X.-H.; Li, B.; Cao, X.-K.; Ye, Z.-L.; Kong, L.-H.; et al. Mutation spectrum of germline cancer susceptibility genes among unselected Chinese colorectal cancer patients. Cancer Manag. Res. 2019, 11, 3721-3739. [CrossRef]

30. Pearlman, R.; Frankel, W.L.; Swanson, B.; Zhao, W.; Yilmaz, A.; Miller, K.; Bacher, J.; Bigley, C.; Nelsen, L.; Goodfellow, P.J.; et al. Prevalence and Spectrum of Germline Cancer Susceptibility Gene Mutations among Patients with Early-Onset Colorectal Cancer. JAMA Oncol. 2017, 3, 464-471. [CrossRef]

31. Bertelsen, B.; Tuxen, I.V.; Yde, C.W.; Gabrielaite, M.; Torp, M.H.; Kinalis, S.; Oestrup, O.; Rohrberg, K.; Spangaard, I.; SantoniRugiu, E.; et al. High frequency of pathogenic germline variants within homologous recombination repair in patients with advanced cancer. NPJ Genom. Med. 2019, 4, 13. [CrossRef]

32. Ceccaldi, R.; Sarangi, P.; D'Andrea, A.D. The Fanconi anaemia pathway: New players and new functions. Nat. Rev. Mol. Cell Biol. 2016, 17, 337-349. [CrossRef] [PubMed]

33. Rodriguez, A.; D'Andrea, A. Fanconi anemia pathway. Curr. Biol. 2017, 27, R986-R988. [CrossRef] [PubMed]

34. Huang, Y.; Li, L. DNA crosslinking damage and cancer-A tale of friend and foe. Transl. Cancer Res. 2013, 2, 144-154. [CrossRef]

35. Zhang, J.; Dewar, J.M.; Budzowska, M.; Motnenko, A.; Cohn, M.A.; Walter, J.C. DNA interstrand cross-link repair requires replication-fork convergence. Nat. Struct. Mol. Biol. 2015, 22, 242-247. [CrossRef] [PubMed]

36. Bhattacharjee, S.; Nandi, S. DNA damage response and cancer therapeutics through the lens of the Fanconi anemia DNA repair pathway. Cell Commun. Signal. 2017, 15, 41. [CrossRef]

37. Helbling-Leclerc, A.; Garcin, C.; Rosselli, F. Beyond DNA repair and chromosome instability-Fanconi anaemia as a cellular senescence-associated syndrome. Cell Death Differ. 2021, 28, 1159-1173. [CrossRef]

38. Clauson, C.; Schärer, O.D.; Niedernhofer, L. Advances in understanding the complex mechanisms of DNA interstrand cross-link repair. Cold Spring Harb. Perspect. Biol. 2013, 5, a012732. [CrossRef]

39. Roy, U.; Schärer, O.D. Involvement of translesion synthesis DNA polymerases in DNA interstrand crosslink repair. DNA Repair 2016, 44, 33-41. [CrossRef]

40. Haince, J.-F.; McDonald, D.; Rodrigue, A.; Déry, U.; Masson, J.-Y.; Hendzel, M.J.; Poirier, G.G. PARP1-dependent kinetics of recruitment of MRE11 and NBS1 proteins to multiple DNA damage sites. J. Biol. Chem. 2008, 283, 1197-1208. [CrossRef]

41. Reilly, N.M.; Novara, L.; Di Nicolantonio, F.; Bardelli, A. Exploiting DNA repair defects in colorectal cancer. Mol. Oncol. 2019, 13, 681-700. [CrossRef] [PubMed]

42. Laurini, E.; Marson, D.; Fermeglia, A.; Aulic, S.; Fermeglia, M.; Pricl, S. Role of Rad51 and DNA repair in cancer: A molecular perspective. Pharmacol. Ther. 2020, 208, 107492. [CrossRef] [PubMed]

43. Xu, G.; Chapman, J.R.; Brandsma, I.; Yuan, J.; Mistrik, M.; Bouwman, P.; Bartkova, J.; Gogola, E.; Warmerdam, D.; Barazas, M.; et al. REV7 counteracts DNA double-strand break resection and affects PARP inhibition. Nature 2015, 521, 541-544. [CrossRef]

44. Xu, T.; Zhang, Y.; Zhang, J.; Qi, C.; Liu, D.; Wang, Z.; Li, Y.; Ji, C.; Li, J.; Lin, X.; et al. Germline Profiling and Molecular Characterization of Early Onset Metastatic Colorectal Cancer. Front. Oncol. 2020, 10, 568911. [CrossRef] [PubMed]

45. Ozawa, H.; Iwatsuki, M.; Mimori, K.; Sato, T.; Johansson, F.; Toh, H.; Watanabe, M.; Mori, M. FANCD2 mRNA overexpression is a bona fide indicator of lymph node metastasis in human colorectal cancer. Ann. Surg. Oncol. 2010, 17, 2341-2348. [CrossRef]

46. Landais, I.; Hiddingh, S.; McCarroll, M.; Yang, C.; Sun, A.; Turker, M.S.; Snyder, J.P.; Hoatlin, M.E. Monoketone analogs of curcumin, a new class of Fanconi anemia pathway inhibitors. Mol. Cancer 2009, 8, 133. [CrossRef]

47. Her, J.; Ray, C.; Altshuler, J.; Zheng, H.; Bunting, S.F. 53BP1 Mediates ATR-Chk1 Signaling and Protects Replication Forks under Conditions of Replication Stress. Mol. Cell Biol. 2018, 38, e00472-17. [CrossRef]

48. Zeman, M.K.; Cimprich, K.A. Causes and consequences of replication stress. Nat. Cell Biol. 2014, 16, 2-9. [CrossRef]

49. Saxena, S.; Dixit, S.; Somyajit, K.; Nagaraju, G. ATR Signaling Uncouples the Role of RAD51 Paralogs in Homologous Recombination and Replication Stress Response. Cell Rep. 2019, 29, 551-559.e4. [CrossRef]

50. Liao, H.; Ji, F.; Helleday, T.; Ying, S. Mechanisms for stalled replication fork stabilization: New targets for synthetic lethality strategies in cancer treatments. EMBO Rep. 2018, 19, e46263. [CrossRef]

51. Skourti-Stathaki, K.; Proudfoot, N.J. A double-edged sword: R loops as threats to genome integrity and powerful regulators of gene expression. Genes Dev. 2014, 28, 1384-1396. [CrossRef] [PubMed]

52. Garcia-Rubio, M.L.; Pérez-Calero, C.; Barroso, S.I.; Tumini, E.; Moyano, E.H.; Rosado, I.V.; Aguilera, A. The Fanconi anemia Pathway Protects Genome Integrity from R-loops. PLoS Genet. 2015, 11, e1005674. [CrossRef] [PubMed]

53. Palovcak, A.; Liu, W.; Yuan, F.; Zhang, Y. Maintenance of genome stability by Fanconi anemia proteins. Cell Biosci. 2017, 7, 8. [CrossRef] [PubMed]

54. Kais, Z.; Rondinelli, B.; Holmes, A.; O'Leary, C.; Kozono, D.; D'Andrea, A.D.; Ceccaldi, R. FANCD2 Maintains Fork Stability in BRCA1/2-Deficient Tumors and Promotes Alternative End-Joining DNA Repair. Cell Rep. 2016, 15, 2488-2499. [CrossRef]

55. Schwab, R.A.; Nieminuszczy, J.; Shah, F.; Langton, J.; Martinez, D.L.; Liang, C.-C.; Cohn, M.A.; Gibbons, R.J.; Deans, A.J.; Niedzwiedz, W. The Fanconi anemia Pathway Maintains Genome Stability by Coordinating Replication and Transcription. Mol. Cell 2015, 60, 351-361. [CrossRef] 
56. Maffia, A.; Ranise, C.; Sabbioneda, S. From R-Loops to G-Quadruplexes: Emerging New Threats for the Replication Fork. Int. J. Mol. Sci. 2020, 21, 1506. [CrossRef]

57. Teng, F.-Y.; Jiang, Z.-Z.; Guo, M.; Tan, X.-Z.; Chen, F.; Xi, X.-G.; Xu, Y. G-quadruplex DNA: A novel target for drug design. Cell Mol. Life Sci. 2021, 78, 6557-6583. [CrossRef]

58. Biffi, G.; Tannahill, D.; Miller, J.; Howat, W.J.; Balasubramanian, S. Elevated levels of G-quadruplex formation in human stomach and liver cancer tissues. PLoS ONE 2014, 9, e102711. [CrossRef]

59. Lowran, K.; Campbell, L.; Popp, P.; Wu, C.G. Assembly of a G-Quadruplex Repair Complex by the FANCJ DNA Helicase and the REV1 Polymerase. Genes 2019, 11, 5. [CrossRef]

60. Wu, C.G.; Spies, M. G-quadruplex recognition and remodeling by the FANCJ helicase. Nucleic Acids Res. 2016, $44,8742-8753$. [CrossRef]

61. Awadasseid, A.; Ma, X.; Wu, Y.; Zhang, W. G-quadruplex stabilization via small-molecules as a potential anti-cancer strategy. Biomed. Pharmacother. 2021, 139, 111550. [CrossRef] [PubMed]

62. Francisco, A.P.; Paulo, A. Oncogene Expression Modulation in Cancer Cell Lines by DNA G-Quadruplex-Interactive Small Molecules. Curr. Med. Chem. 2018, 24, 4873-4904. [CrossRef] [PubMed]

63. Estep, K.N.; Butler, T.J.; Ding, J.; Brosh, R.M. G4-Interacting DNA Helicases and Polymerases: Potential Therapeutic Targets. Curr Med. Chem. 2019, 26, 2881-2897. [CrossRef] [PubMed]

64. Brito, H.; Martins, A.C.; Lavrado, J.; Mendes, M.; Francisco, A.P.; Santos, S.A.; Ohnmacht, S.A.; Kim, N.-S.; Rodrigues, C.M.; Moreira, R.; et al. Targeting KRAS Oncogene in Colon Cancer Cells with 7-Carboxylate Indolo[3,2-b]quinoline Tri-Alkylamine Derivatives. PLoS ONE 2015, 10, e0126891. [CrossRef]

65. Wu, Y.; Shin-Ya, K.; Brosh, R.M., Jr. FANCJ helicase defective in Fanconia anemia and breast cancer unwinds G-quadruplex DNA to defend genomic stability. Mol. Cell Biol. 2008, 28, 4116-4128. [CrossRef]

66. Henderson, A.; Wu, Y.; Huang, Y.C.; Chavez, E.A.; Platt, J.; Johnson, F.B.; Brosh, R.M., Jr.; Sen, D.; Lansdorp, P.M. Detection of G-quadruplex DNA in mammalian cells. Nucleic Acids Res. 2014, 42, 860-869. [CrossRef]

67. Kolinjivadi, A.M.; Sannino, V.; De Antoni, A.; Técher, H.; Baldi, G.; Costanzo, V. Moonlighting at replication forks-A new life for homologous recombination proteins BRCA1, BRCA2 and RAD51. FEBS Lett. 2017, 591, 1083-1100. [CrossRef]

68. García-De-Teresa, B.; Rodríguez, A.; Frias, S. Chromosome Instability in Fanconi anemia: From Breaks to Phenotypic Consequences. Genes 2020, 11, 1528. [CrossRef]

69. Chen, X.; Bosques, L.; Sung, P.; Kupfer, G.M. A novel role for non-ubiquitinated FANCD2 in response to hydroxyurea-induced DNA damage. Oncogene 2016, 35, 22-34. [CrossRef]

70. Ghose, A.; Moschetta, M.; Pappas-Gogos, G.; Sheriff, M.; Boussios, S. Genetic Aberrations of DNA Repair Pathways in Prostate Cancer: Translation to the Clinic. Int. J. Mol. Sci. 2021, 22, 9783. [CrossRef]

71. Chang, P.-Y.; Chang, S.-C.; Wang, M.-C.; Chen, J.-S.; Tsai, W.-S.; You, J.-F.; Chen, C.-C.; Liu, H.-L.; Chiang, J.-M. Pathogenic Germline Mutations of DNA Repair Pathway Components in Early-Onset Sporadic Colorectal Polyp and Cancer Patients. Cancers 2020, 12, 3560. [CrossRef] [PubMed]

72. AlDubayan, S.H.; Giannakis, M.; Moore, N.D.; Han, G.C.; Reardon, B.; Hamada, T.; Mu, X.J.; Nishihara, R.; Qian, Z.; Liu, L.; et al Inherited DNA-Repair Defects in Colorectal Cancer. Am. J. Hum. Genet. 2018, 102, 401-414. [CrossRef] [PubMed]

73. Degrolard-Courcet, E.; Sokolowska, J.; Padeano, M.-M.; Guiu, S.; Bronner, M.; Chery, C.; Coron, F.; Lepage, C.; Chapusot, C.; Loustalot, C.; et al. Development of primary early-onset colorectal cancers due to biallelic mutations of the FANCD1/BRCA2 gene. Eur. J. Hum. Genet. 2014, 22, 979-987. [CrossRef] [PubMed]

74. Palmieri Molecular analysis of Fanconi anemia and mismatch repair genes in patients with colorectal carcinoma. Oncol. Rep. 2011, 25, 899-904. [CrossRef]

75. Tham, K.-C.; Kanaar, R.; Lebbink, J.H.G. Mismatch repair and homeologous recombination. DNA Repair 2016, 38, 75-83. [CrossRef]

76. Rahman, N.; Scott, R.H. Cancer genes associated with phenotypes in monoallelic and biallelic mutation carriers: New lessons from old players. Hum. Mol. Genet. 2007, 16, R60-R66. [CrossRef]

77. Peng, M.; Litman, R.; Xie, J.; Sharma, S.; Brosh, R.M., Jr.; Cantor, S.B. The FANCJ/MutL $\alpha$ interaction is required for correction of the cross-link response in FA-J cells. EMBO J. 2007, 26, 3238-3249. [CrossRef]

78. Wang, Y.; Cortez, D.; Yazdi, P.; Neff, N.; Elledge, S.J.; Qin, J. BASC, a super complex of BRCA1-associated proteins involved in the recognition and repair of aberrant DNA structures. Genes Dev. 2000, 14, 927-939. [CrossRef]

79. Williams, S.A.; Wilson, J.B.; Clark, A.P.; Mitson-Salazar, A.; Tomashevski, A.; Ananth, S.; Glazer, P.M.; Semmes, O.J.; Bale, A.E.; Jones, N.J.; et al. Functional and physical interaction between the mismatch repair and FA-BRCA pathways. Hum. Mol. Genet. 2011, 20, 4395-4410. [CrossRef]

80. Szklarczyk, D.; Gable, A.L.; Nastou, K.C.; Lyon, D.; Kirsch, R.; Pyysalo, S.; Doncheva, N.T.; Legeay, M.; Fang, T.; Bork, P.; et al. The STRING database in 2021: Customizable protein-protein networks, and functional characterization of user-uploaded gene/measurement sets. Nucleic Acids Res. 2021, 49, D605-D612. [CrossRef]

81. Shannon, P.; Markiel, A.; Ozier, O.; Baliga, N.S.; Wang, J.T.; Ramage, D.; Amin, N.; Schwikowski, B.; Ideker, T. Cytoscape: A software environment for integrated models of biomolecular interaction networks. Genome Res. 2003, 13, 2498-2504. [CrossRef] [PubMed] 
82. Heald, B.; Kupfer, S.S.; Hampel, H.; Church, J.; Dudley, B.; Hall, M.J.; Mork, M.E.; Singh, A.; Stoffel, E.; Stoll, J.; et al. Collaborative Group of the Americas on Inherited Gastrointestinal Cancer Position statement on multigene panel testing for patients with colorectal cancer and/or polyposis. Fam. Cancer 2020, 19, 223-239. [CrossRef] [PubMed]

83. Akcay, I.M.; Celik, E.; Agaoglu, N.B.; Alkurt, G.; Msc, T.K.A.; Yildiz, J.; Enc, F.; Kir, G.; Canbek, S.; Kilic, A.; et al. Germline pathogenic variant spectrum in 25 cancer susceptibility genes in Turkish breast and colorectal cancer patients and elderly controls. Int. J. Cancer 2021, 148, 285-295. [CrossRef] [PubMed]

84. Toh, M.R.; Chiang, J.B.; Chong, S.T.; Chan, S.H.; Ishak, N.D.B.; Courtney, E.; Lee, W.H.; Syed Abdillah Al, S.M.F.B.; Allen, J.C.; Lim, K.H.; et al. Germline Pathogenic Variants in Homologous Recombination and DNA Repair Genes in an Asian Cohort of Young-Onset Colorectal Cancer. JNCI Cancer Spectr. 2018, 2, pky054. [CrossRef]

85. Garre, P.; Martín, L.; Sanz, J.; Romero, A.; Tosar, A.; Bando, I.; Llovet, P.; Diaque, P.; García-Paredes, B.; Rubio, P.G.; et al. BRCA2gene: A candidate for clinical testing in familial colorectal cancer type X. Clin. Genet. 2015, 87, 582-587. [CrossRef]

86. Yurgelun, M.B.; Allen, B.; Kaldate, R.R.; Bowles, K.R.; Judkins, T.; Kaushik, P.; Roa, B.B.; Wenstrup, R.J.; Hartman, A.-R.; Syngal, S. Identification of a Variety of Mutations in Cancer Predisposition Genes in Patients with Suspected Lynch Syndrome. Gastroenterology 2015, 149, 604-613.e20. [CrossRef]

87. Stoffel, E.M.; Koeppe, E.; Everett, J.; Ulintz, P.; Kiel, M.; Osborne, J.; Williams, L.; Hanson, K.; Gruber, S.B.; Rozek, L.S. Germline Genetic Features of Young Individuals with Colorectal Cancer. Gastroenterology 2018, 154, 897-905.e1. [CrossRef]

88. Naseem, M.; Xiu, J.; Salem, M.E.; Goldberg, R.M.; Vanderwalde, A.M.; Grothey, A.; Philip, P.A.; Seeber, A.; Puccini, A.; Tokunaga, R.; et al. Characteristics of colorectal cancer (CRC) patients with BRCA1 and BRCA2 mutations. J. Clin. Oncol. 2019, 37, 606. [CrossRef]

89. Mikaeel, R.R.; Young, J.P.; Li, Y.; Smith, E.; Horsnell, M.; Uylaki, W.; Rico, G.T.; Poplawski, N.K.; Hardingham, J.E.; Tomita, Y.; et al. Survey of germline variants in cancer-associated genes in young adults with colorectal cancer. Genes Chromosom. Cancer 2021, 65, 105-113. [CrossRef]

90. Suchy, J.; Cybulski, C.; Górski, B.; Huzarski, T.; Byrski, T.; Dębniak, T.; Gronwald, J.; Jakubowska, A.; Wokołorczyk, D.; Kurzawski, G.; et al. BRCA1 mutations and colorectal cancer in Poland. Fam. Cancer 2010, 9, 541-544. [CrossRef]

91. Phelan, C.M.; Iqbal, J.; Lynch, H.T.; Lubinski, J.; Gronwald, J.; Moller, P.; Ghadirian, P.; Foulkes, W.D.; Armel, S.; Eisen, A.; et al. Incidence of colorectal cancer in BRCA1 and BRCA2 mutation carriers: Results from a follow-up study. Br. J. Cancer 2014, 110, 530-534. [CrossRef] [PubMed]

92. Cullinane, C.M.; Creavin, B.; O'Connell, E.P.; Kelly, L.; O'Sullivan, M.J.; Corrigan, M.A.; Redmond, H.P. Risk of colorectal cancer associated with BRCA1 and/or BRCA2 mutation carriers: Systematic review and meta-analysis. Br. J. Surg. 2020, 107, 951-959. [CrossRef] [PubMed]

93. Maccaroni, E.; Giampieri, R.; Lenci, E.; Scortichini, L.; Bianchi, F.; Belvederesi, L.; Brugiati, C.; Pagliaretta, S.; Ambrosini, E.; Berardi, R. BRCA mutations and gastrointestinal cancers: When to expect the unexpected? World J. Clin. Oncol. 2021, 12, 565-580. [CrossRef] [PubMed]

94. Martín-Morales, L.; Garre, P.; Lorca, V.; Cazorla, M.; Llovet, P.; Bando, I.; García-Barberan, V.; González-Morales, M.L.; EstebanJurado, C.; De La Hoya, M.; et al. BRIP1, a Gene Potentially Implicated in Familial Colorectal Cancer Type X. Cancer Prev. Res. 2020, 14, 185-194. [CrossRef]

95. Ali, M.; DeLozier, C.D.; Chaudhary, U. BRIP-1 germline mutation and its role in colon cancer: Presentation of two case reports and review of literature. BMC Med. Genet. 2019, 20, 75. [CrossRef]

96. Cannon-Albright, L.A.; Teerlink, C.C.; Stevens, J.; Snow, A.K.; Thompson, B.A.; Bell, R.; Nguyen, K.N.; Sargent, N.R.; Kohlmann, W.K.; Neklason, D.W.; et al. FANCM c5791C $>$ T stopgain mutation (rs144567652) is a familial colorectal cancer risk factor. Mol. Genet. Genom. Med. 2020, 8, e1532. [CrossRef]

97. Innocenti, F.; Rashid, N.; Wancen, M.; Ou, F.-S.; Qu, X.; Denning, S.; Bertagnoli, M.; Blanke, C.D.; Venook, A.; Kabbarah, O.; et al. Next-generation sequencing (NGS) in metastatic colorectal cancer (mCRC): Novel mutated genes and their effect on response to therapy (Alliance). Ann. Oncol. 2019, 30, 198-199. [CrossRef]

98. Martínez-Jiménez, F.; Muiños, F.; Sentís, I.; Deu-Pons, J.; Reyes-Salazar, I.; Arnedo-Pac, C.; Mularoni, L.; Pich, O.; Bonet, J.; Kranas, H.; et al. A compendium of mutational cancer driver genes. Nat. Rev. Cancer 2020, 20, 555-572. [CrossRef]

99. GDC Data Portal-National Cancer Institute. Available online: www.portal.gdc.cancer.gov (accessed on 26 February 2022).

100. Qin, C.-J.; Song, X.-M.; Chen, Z.-H.; Ren, X.-Q.; Xu, K.-W.; Jing, H.; He, Y.-L. XRCC2 as a predictive biomarker for radioresistance in locally advanced rectal cancer patients undergoing preoperative radiotherapy. Oncotarget 2015, 6, 32193-32204. [CrossRef]

101. Marsh, S.; McLeod, H.; Dolan, E.; Rabik, C.; Shukla, S.J.; Gong, L.; Hernandez-Boussard, T.; Lou, X.J.; Klein, T.E.; Altman, R.B. Platinum pathway. Pharmacogenet. Genom. 2009, 19, 563-564. [CrossRef]

102. Cepeda, V.; Fuertes, M.A.; Castilla, J.; Alonso, C.; Quevedo, C.; Perez, J.M. Biochemical Mechanisms of Cisplatin Cytotoxicity. Anti-Cancer Agents Med. Chem. 2007, 7, 3-18. [CrossRef] [PubMed]

103. Nakanishi, R.; Kitao, H.; Fujinaka, Y.; Yamashita, N.; Iimori, M.; Tokunaga, E.; Yamashita, N.; Morita, M.; Kakeji, Y.; Maehara, Y. FANCJ expression predicts the response to 5-fluorouracil-based chemotherapy in MLH1-proficient colorectal cancer. Ann. Surg. Oncol. 2012, 19, 3627-3635. [CrossRef] [PubMed]

104. Ihara, K.; Yamaguchi, S.; Ueno, N.; Tani, Y.; Shida, Y.; Ogata, H.; Domeki, Y.; Okamoto, K.; Nakajima, M.; Sasaki, K.; et al. Expression of DNA double-strand break repair proteins predicts the response and prognosis of colorectal cancer patients undergoing oxaliplatin-based chemotherapy. Oncol. Rep. 2016, 35, 1349-1355. [CrossRef] [PubMed] 
105. Wu, M.; Li, X.; Huang, W.; Chen, Y.; Wang, B.; Liu, X. Ubiquitin-conjugating enzyme E2T(UBE2T) promotes colorectal cancer progression by facilitating ubiquitination and degradation of p53. Clin. Res. Hepatol. Gastroenterol. 2021, 45, 101493. [CrossRef]

106. Wu, X.; Liu, G.; Liu, R.; He, J.; Wang, G.; Zhang, H.; Liu, T.; Bai, J.; Cheng, N.; Qiu, J. Expression of ubiquitin-conjugating enzyme E2T in colorectal cancers and clinical implications. Oncol. Lett. 2020, 20, 275. [CrossRef]

107. Zhang, Y.-Z.; An, J.-H.; Liu, Y.-X.; Wu, X.-C.; Han, S.-S.; Ren, X.-Q.; Qin, C.-J. XRCC2-Deficient Cells are Highly Sensitive to 5-Fluorouracil in Colorectal Cancer. Cell. Physiol. Biochem. 2017, 43, 1207-1219. [CrossRef]

108. Tennstedt, P.; Fresow, R.; Simon, R.; Marx, A.; Terracciano, L.; Petersen, C.; Sauter, G.; Dikomey, E.; Borgmann, K. RAD51 overexpression is a negative prognostic marker for colorectal adenocarcinoma. Int. J. Cancer 2013, 132, 2118-2126. [CrossRef]

109. Lemonidis, K.; Arkinson, C.; Rennie, M.L.; Walden, H. Mechanism, specificity, and function of FANCD2-FANCI ubiquitination and deubiquitination. FEBS J. 2021. [CrossRef]

110. Liu, C.; Gao, J.; LE, Y.; Zhong, X.; Chen, Y.; Wang, H. Expression of FANCD2 in Colorectal Cancer and Its Correlation with Prognosis. Chin. J. Gastroenterol. 2014, 404-407.

111. Lee, J.-H.; Bae, A.-N.; Jung, S.-J. Clinicopathological and Prognostic Characteristics of RAD51 in Colorectal Cancer. Medicina 2020, 56, 48. [CrossRef]

112. Slupianek, A.; Hoser, G.; Majsterek, I.; Bronisz, A.; Malecki, M.; Blasiak, J.; Fishel, R.; Skorski, T. Fusion tyrosine kinases induce drug resistance by stimulation of homology-dependent recombination repair, prolongation of G2/M phase, and protection from apoptosis. Mol. Cell. Biol. 2002, 22, 4189-4201. [CrossRef] [PubMed]

113. Vispe, S.; Cazaux, C.; Lesca, C.; Defais, M. Overexpression of Rad51 protein stimulates homologous recombination and increases resistance of mammalian cells to ionizing radiation. Nucleic Acids Res. 1998, 26, 2859-2864. [CrossRef] [PubMed]

114. Brosh, R.M., Jr.; Cantor, S.B. Molecular and cellular functions of the FANCJ DNA helicase defective in cancer and in Fanconi anemia. Front. Genet. 2014, 5, 372. [CrossRef] [PubMed]

115. Du, C.; Peng, Y.; He, Y.; Chen, G.; Chen, H. Low levels of BRCA1 protein expression predict a worse prognosis in stage I-II colon cancer. Int. J. Biol. Markers 2021, 36, 47-53. [CrossRef]

116. Leaf, S.; Carlsen, L.; El-Deiry, W.S. Opposing effects of BRCA1 mRNA expression on patient survival in breast and colorectal cancer and variations among African American, Asian, and younger patients. Oncotarget 2021, 12, 1992-2005. [CrossRef]

117. Yuanming, L.; Lineng, Z.; Baorong, S.; Junjie, P.; Sanjun, C. BRCA1 and ERCC1mRNA levels are associated with lymph node metastasis in Chinese patients with colorectal cancer. BMC Cancer 2013, 13, 103. [CrossRef]

118. Rajarajan, S.; Anupamam, A.; Jose, B.; Correa, M.; Sengupta, S.; Prabhu, J.S. Identification of colorectal cancers with defective DNA damage repair by immunohistochemical profiling of mismatch repair proteins, CDX2 and BRCA1. Mol. Clin. Oncol. 2020, 13, 57. [CrossRef]

119. Wang, G.-H.; Zhao, C.-M.; Huang, Y.; Wang, W.; Zhang, S.; Wang, X. BRCA1 and BRCA2 expression patterns and prognostic significance in digestive system cancers. Hum. Pathol. 2018, 71, 135-144. [CrossRef]

120. Grabsch, H.; Dattani, M.; Barker, L.; Maughan, N.; Maude, K.; Hansen, O.; Gabbert, H.E.; Quirke, P.; Mueller, W. Expression of DNA double-strand break repair proteins ATM and BRCA1 predicts survival in colorectal cancer. Clin. Cancer Res. 2006, 12, 1494-1500. [CrossRef]

121. Ma, J.; Setton, J.; Lee, N.Y.; Riaz, N.; Powell, S.N. The therapeutic significance of mutational signatures from DNA repair deficiency in cancer. Nat. Commun. 2018, 9, 3292. [CrossRef]

122. Hosoya, N.; Miyagawa, K. Targeting DNA damage response in cancer therapy. Cancer Sci. 2014, 105, 370-388. [CrossRef] [PubMed]

123. Zhang, B.; Tang, C.; Yao, Y.; Chen, X.; Zhou, C.; Wei, Z.; Xing, F.; Chen, L.; Cai, X.; Zhang, Z.; et al. The tumor therapy landscape of synthetic lethality. Nat. Commun. 2021, 12, 1275. [CrossRef] [PubMed]

124. Tomasini, P.P.; Guecheva, T.N.; Leguisamo, N.M.; Péricart, S.; Brunac, A.-C.; Hoffmann, J.S.; Saffi, J. Analyzing the Opportunities to Target DNA Double-Strand Breaks Repair and Replicative Stress Responses to Improve Therapeutic Index of Colorectal Cancer. Cancers 2021, 13, 3130. [CrossRef] [PubMed]

125. Shah, S.; Rachmat, R.; Enyioma, S.; Ghose, A.; Revythis, A.; Boussios, S. BRCA Mutations in Prostate Cancer: Assessment, Implications and Treatment Considerations. Int. J. Mol. Sci. 2021, 22, 12628. [CrossRef]

126. Krajewska, M.; Fehrmann, R.S.; Schoonen, P.M.; Labib, S.; de Vries, E.G.; Franke, L.; Van Vugt, M.A.T.M. ATR inhibition preferentially targets homologous recombination-deficient tumor cells. Oncogene 2015, 34, 3474-3481. [CrossRef]

127. Gaillard, H.; Garcia-Muse, T.; Aguilera, A. Replication stress and cancer. Nat. Rev. Cancer 2015, 15, 276-289. [CrossRef]

128. Srinivas, U.S.; Dyczkowski, J.; Beißbarth, T.; Gaedcke, J.; Mansour, W.Y.; Borgmann, K.; Dobbelstein, M. 5-Fluorouracil sensitizes colorectal tumor cells towards double stranded DNA breaks by interfering with homologous recombination repair. Oncotarget 2015, 6, 12574-12586. [CrossRef]

129. Manic, G.; Musella, M.; Corradi, F.; Sistigu, A.; Vitale, S.; Rehim, S.S.A.; Mattiello, L.; Malacaria, E.; Galassi, C.; Signore, M.; et al. Control of replication stress and mitosis in colorectal cancer stem cells through the interplay of PARP1, MRE11 and RAD51. Cell Death Differ. 2021, 28, 2060-2082. [CrossRef] 
130. Manic, G.; Signore, M.; Sistigu, A.; Russo, G.; Corradi, F.; Siteni, S.; Musella, M.; Vitale, S.; De Angelis, M.L.; Pallocca, M.; et al. CHK1-targeted therapy to deplete DNA replication-stressed, p53-deficient, hyperdiploid colorectal cancer stem cells. Gut 2018, 67, 903-917. [CrossRef]

131. Mattiello, L.; Rehim, S.S.A.; Musella, M.; Sistigu, A.; Guarracino, A.; Vitale, S.; Corradi, F.; Galassi, C.; Sperati, F.; Manic, G.; et al. The Targeting of MRE11 or RAD51 Sensitizes Colorectal Cancer Stem Cells to CHK1 Inhibition. Cancers 2021, 13, 1957. [CrossRef]

132. Smeby, J.; Kryeziu, K.; Berg, K.C.; Eilertsen, I.A.; Eide, P.W.; Johannessen, B.; Guren, M.G.; Nesbakken, A.; Bruun, J.; Lothe, R.A.; et al. Molecular correlates of sensitivity to PARP inhibition beyond homologous recombination deficiency in preclinical models of colorectal cancer point to wild-type TP53 activity. EBioMedicine 2020, 59, 102923. [CrossRef] [PubMed]

133. Arena, S.; Corti, G.; Durinikova, E.; Montone, M.; Reilly, N.M.; Russo, M.; Lorenzato, A.; Arcella, P.; Lazzari, L.; Rospo, G.; et al. A Subset of Colorectal Cancers with Cross-Sensitivity to Olaparib and Oxaliplatin. Clin. Cancer Res. 2020, 26, 1372-1384. [CrossRef] [PubMed]

134. Kalimutho, M.; Bain, A.L.; Mukherjee, B.; Nag, P.; Nanayakkara, D.M.; Harten, S.K.; Harris, J.L.; Subramanian, G.N.; Sinha, D.; Shirasawa, S.; et al. Enhanced dependency of KRAS-mutant colorectal cancer cells on RAD51-dependent homologous recombination repair identified from genetic interactions inSaccharomyces cerevisiae. Mol. Oncol. 2017, 11, 470-490. [CrossRef] [PubMed]

135. Li, D.; Li, X.; Li, G.; Meng, Y.; Jin, Y.; Shang, S.; Li, Y. Alpinumisoflavone causes DNA damage in Colorectal Cancer Cells via blocking DNA repair mediated by RAD51. Life Sci. 2019, 216, 259-270. [CrossRef]

136. Mehta, P.; Bothra, S.J. PARP inhibitors in hereditary breast and ovarian cancer and other cancers: A review. Adv. Genet. 2021, 108, 35-80. [CrossRef]

137. Messina, C.; Cattrini, C.; Soldato, D.; Vallome, G.; Caffo, O.; Castro, E.; Olmos, D.; Boccardo, F.; Zanardi, E. BRCA Mutations in Prostate Cancer: Prognostic and Predictive Implications. J. Oncol. 2020, 2020, 4986365. [CrossRef]

138. Czito, B.G.; Deming, D.A.; Jameson, G.S.; Mulcahy, M.F.; Vaghefi, H.; Dudley, M.W.; Holen, K.D.; DeLuca, A.; Mittapalli, R.K.; Munasinghe, W.; et al. Safety and tolerability of veliparib combined with capecitabine plus radiotherapy in patients with locally advanced rectal cancer: A phase 1b study. Lancet Gastroenterol. Hepatol. 2017, 2, 418-426. [CrossRef]

139. Pishvaian, M.J.; Slack, R.S.; Jiang, W.; He, A.R.; Hwang, J.J.; Hankin, A.; Dorsch-Vogel, K.; Kukadiya, D.; Weiner, L.M.; Marshall, J.L.; et al. A phase 2 study of the PARP inhibitor veliparib plus temozolomide in patients with heavily pretreated metastatic colorectal cancer. Cancer 2018, 124, 2337-2346. [CrossRef]

140. Paviolo, N.S.; De La Vega, M.B.; Pansa, M.F.; García, I.A.; Calzetta, N.L.; Soria, G.; Gottifredi, V. Persistent double strand break accumulation does not precede cell death in an Olaparib-sensitive BRCA-deficient colorectal cancer cell model. Genet. Mol. Biol. 2020, 43, e20190070. [CrossRef]

141. Gorbunova, V.; Beck, J.T.; Hofheinz, R.-D.; Garcia-Alfonso, P.; Nechaeva, M.; Gracian, A.C.; Mangel, L.; Fernandez, E.E.; Deming, D.A.; Ramanathan, R.K.; et al. A phase 2 randomised study of veliparib plus FOLFIRI \pm bevacizumab versus placebo plus FOLFIRI \pm bevacizumab in metastatic colorectal cancer. Br. J. Cancer 2018, 120, 183-189. [CrossRef]

142. Berlin, J.; Ramanathan, R.K.; Strickler, J.; Subramaniam, D.S.; Marshall, J.; Kang, Y.-K.; Hetman, R.; Dudley, M.W.; Zeng, J.; Nickner, C.; et al. A phase 1 dose-escalation study of veliparib with bimonthly FOLFIRI in patients with advanced solid tumours. Br. J. Cancer 2018, 118, 938-946. [CrossRef] [PubMed]

143. Williams, S.M.G.; Kuznicki, A.M.; Andrade, P.; Dolinski, B.M.; Elbi, C.; O'Hagan, R.C.; Toniatti, C. Treatment with the PARP inhibitor, niraparib, sensitizes colorectal cancer cell lines to irinotecan regardless of MSI/MSS status. Cancer Cell Int. 2015, 15, 14. [CrossRef] [PubMed]

144. Reisländer, T.; Lombardi, E.P.; Groelly, F.J.; Miar, A.; Porru, M.; Di Vito, S.; Wright, B.; Lockstone, H.; Biroccio, A.; Harris, A.; et al BRCA2 abrogation triggers innate immune responses potentiated by treatment with PARP inhibitors. Nat. Commun. 2019, 10, 3143. [CrossRef] [PubMed]

145. Tiong, K.-L.; Chang, K.-C.; Yeh, K.-T.; Liu, T.-Y.; Wu, J.-H.; Hsieh, P.-H.; Lin, S.-H.; Lai, W.-Y.; Hsu, Y.-C.; Chen, J.-Y.; et al. CSNK1E/CTNNB1 are synthetic lethal to TP53 in colorectal cancer and are markers for prognosis. Neoplasia 2014, 16, 441-450. [CrossRef]

146. Makondi, P.T.; Lee, C.-H.; Huang, C.-Y.; Chu, C.-M.; Chang, Y.-J.; Wei, P.-L. Prediction of novel target genes and pathways involved in bevacizumab-resistant colorectal cancer. PLOS ONE 2018, 13, e0189582. [CrossRef]

147. Schrempf, A.; Slyskova, J.; Loizou, J.I. Targeting the DNA Repair Enzyme Polymerase $\theta$ in Cancer Therapy. Trends Cancer 2020, 7 , 98-111. [CrossRef]

148. Soyano, A.E.; Baldeo, C.; Kasi, P.M. BRCA Mutation and Its Association with Colorectal Cancer. Clin. Color. Cancer 2018, 17, e647-e650. [CrossRef]

149. Wang, Q.; Wang, Y.; Du, L.; Xu, C.; Sun, Y.; Yang, B.; Sun, Z.; Fu, Y.; Cai, L.; Fan, S.; et al. shRNA-mediated XRCC2 gene knockdown efficiently sensitizes colon tumor Cells to X-ray irradiation in vitro and in vivo. Int. J. Mol. Sci. 2014, 15, 2157-2171. [CrossRef]

150. Xu, K.; Song, X.; Chen, Z.; Qin, C. miR-7 inhibits colorectal cancer cell proliferation and induces apoptosis by targeting XRCC2. OncoTargets Ther. 2014, 7, 325-332. [CrossRef] 
151. Andreassen, P.R.; Hanenberg, H. XRCC2 (X-ray repair cross complementing 2). Atlas Genet. Cytogenet. Oncol. Haematol. 2019, 23, 1-7. [CrossRef]

152. Park, J.-Y.; Virts, E.L.; Jankowska, A.; Wiek, C.; Othman, M.; Chakraborty, S.C.; Vance, G.H.; Alkuraya, F.S.; Hanenberg, H.; Andreassen, P.R. Complementation of hypersensitivity to DNA interstrand crosslinking agents demonstrates thatXRCC2is a Fanconi anaemia gene. J. Med. Genet. 2016, 53, 672-680. [CrossRef] [PubMed]

153. Xu, K.; Song, X.; Chen, Z.; Qin, C.; He, Y.; Zhan, W. XRCC2 Promotes Colorectal Cancer Cell Growth, Regulates Cell Cycle Progression, and Apoptosis. Medicine 2014, 93, e294. [CrossRef] [PubMed]

154. Sun, X.; Hou, W.; Liu, X.; Chai, J.; Guo, H.; Yu, J. Targeting REV7 effectively reverses 5-FU and oxaliplatin resistance in colorectal cancer. Cancer Cell Int. 2020, 20, 580. [CrossRef] [PubMed] 